\title{
LOS TRABAJOS Y LOS MESES EN EL MOSAICO ROMÁNICO DE PANTALEÓN EN LA CATEDRAL DE OTRANTO
}

\author{
José Javier López de Ocáriz Alzola \\ Universidad de La Rioja
}

\begin{abstract}
RESUMEN: El mayor mosaico románico de Europa (1163-1165) cubre el pavimento de la catedral italiana de Otranto en Apulia, situada entre Oriente y Occidente. Es la obra maestra: opvs insigne, del presbítero Pantaleón patrocinado por el arzobispo Jonathas. Seleccionamos el Calendario con el Zodíaco y los Meses, que encabeza la nave central, para su estudio. Representa las faenas agrarias del cultivo del trigo y la vid, además de la matanza del cerdo, reservando a la mujer la cocina. Sorprenden dos temas de raigambre clásica: el Espinario, y TeIlus: la Tierra nutricia. Procedemos al análisis iconográfico de cada Mes, acompañado de textos ilustrativos del griego Hesíodo, que no desentonan pese al salto cronológico. Lo encuadramos en el ritmo temporal del Zodíaco y otras constelaciones aludidas. En el mosaico presidido por el Árbol de la Vida, la contigua escena bíblica de la caída de Adán y Eva proporciona la clave para explicar el calendario: el duro trabajo es un castigo por desobedecer al creador, lo que ya evocaba Hesíodo en sus reflexiones. Pero, por suerte, en la fiesta de Pascua el trabajo puede transformarse en liberación, al pasar de la Terra maledicta al Exultet et gaudeat Tellus.
\end{abstract}

Palabras clave: Otranto, Pantaleón, calendario, Trabajos de los Meses, zodíaco, faenas agrícolas, mosaico, mensario, Hesíodo, Tellus, Exultet, Espinario, románico, Edad Media, Laboratores, tiempo, temporalidad, constelaciones.

\section{LES TRAVAUX ET LES MOIS DE LA MOSAÏQUE DE PANTALEONE DANS LA CATHÉDRALE D'OTRANTE}

RÉSUMÉ: La plus grande mosaïque romane de l'Europe (1163-1165) décore le pavement de la cathédrale italienne d'Otrante (Pouilles), située entre l'Orient et I'Occident. Il s'agit du chef-d'oeuvre: opvs insigne, du prêtre Pantaleone, sou- 
tenu par l'archevêque Jonathas. En haut de la nef centrale présidée par l'Arbre de la Vie, se trouve le Calendrier, avec le Zodiaque et les Mois, dont nous avons choisi d'entreprendre l'étude. La culture des blés, les travaux de la vigne et l'abbatage des porcs y sont representés, tandis que les femmes s'occupent de la cuisine. Deux sujets classiques se glissent parmi les travaux: le Tireur d'épine, et Tellus: la Terre nourricière. Pour enrichir l'analyse iconographique de chaque Mois, nous y ajoutons des textes éclairants du grec Hésiode, malgré le décalage chronologique. L'ensemble s'associe au rythme temporel des signes du Zodiaque et des autres constellations suggérées. Au-dessus du Calendrier se trouve une scène biblique, la chute d'Adam et Ève, qui donne du sens aux travaux: fruit du péché originel, I’homme est tenu de travailler durement pour avoir désobéi au créateur, ce qui s'accorde bien aux réflexions d'Hésiode. Mais, heureusement, à Pâques le travail devient une délivrance, en passant de la Terra maledicta à l'Exultet et gaudeat Tellus.

Mots clés: Otrante, Pantaleone, calendrier, Travaux des Mois, zodiaque, techniques agricoles, mosaïque, ménologe, Hésiode, Tellus, Exultet, tireur d'épine, roman, Moyen Âge, laboratores, temps, temporalité, constellations.

\section{Otranto en su contexto medieval}

Otranto, la antigua Hydruntum, es la ciudad italiana situada más al este. Por ello se manifiesta como clave de unión entre Oriente y Occidente. En la Edad Media allí se intercambia el variado acervo cultural y artístico bizantino con el despegue occidental del románico. Convergen lenguas, culturas y cultos procedentes de Asia, África o Europa.

Podemos comenzar presentando una historia abreviada de Otranto medieval. Era tierra bizantina desde mediados del siglo VI, bajo Justiniano, hasta la conquista normanda de hacia 1070. Eso suponía cinco siglos en que la lengua, las estructuras socio-políticas, el culto y la liturgia eran greco-bizantinos. Otranto era capital de provincia, pero la perdió con la conquista por parte del normando Roberto Guiscardo de toda la comarca de Bari en las campañas de 1069 a 1071. Los vencedores impusieron sus normas y fueron vistos como agresores. Una década más tarde, Guillermo, el arzobispo de Otranto, decidió construir allí una catedral que sirviera de unión para vencedores y vencidos.

En el cerro Idro, sobre el solar de una domus romana con mosaicos, y de una iglesia paleocristiana, con el patrocinio de Roger I (1085-1101) y la colaboración popular, Guillermo edificó en sólo ocho años, de 1080 a1088, la catedral. Su estructura es basilical, espaciosa en sus tres naves y profundo presbiterio, donde dos capillas oblongas encuadran el ábside curvo de la capilla mayor. Las dimensiones son amplias, del orden de 50 × 25 m. Subyace una cripta, con bóve- 
das sostenidas por 42 columnas, donde se aprecian capiteles en buena parte reutilizados.

Recibió su consagración el 1 de agosto de 1088 de manos del arzobispo de Benevento Roffredo como delegado pontificio de Urbano II, secundado por los arzobispos de Otranto, Bari, Tarento y Brindisi, y en presencia del Duque de Sicilia Roger I. Tuvo que esperar casi ochenta años para completar su ornamentación con el espléndido pavimento musivo.

Predomina en las basílicas cristinas el dinamismo espacial, gracias a la tensión del espacio camino de su eje, impulsando hacia el ábside, tal como lo requiere la liturgia procesional. Un ejemplo peculiar lo constituyen los mosaicos de San Apolinar Nuevo de Ravena, donde las procesiones de Mártires y Vírgenes convergen hacia el presbiterio. Otranto sigue el mismo prototipo, aunque sus muros aparecen blanqueados, desprovistos de sus antiguas pinturas murales en el terrible ataque del ejército turco otomano, el año 1481, al mando de Ahmet Pachá que, en cambio, respetó sorprendentemente los mosaicos de pavimento, pese a que, según unos, convirtió temporalmente la catedral en mezquita o, según otros, por desprecio la dedicó a cuadra de caballos.

En el ataque de Alfonso de Aragón, el futuro rey de Nápoles que liberó Otranto del dominio turco, fue destruida la fachada occidental, reconstruida por el mismo Alfonso en estilo tardogótico. También los turcos habían destruido la riquísima biblioteca del Monasterio de San Nicola di Casole, a dos kilómetros de Otranto. No hay duda que este Monasterio de monjes contemplativos, adscritos a la Regla griega de San Basilio, fue el soporte cultural y espiritual de Otranto, pues en el siglo XII contaba con scriptorium, biblioteca, residencia universitaria, y escuela pictórica de la que salieron maestros como Pablo de Otranto, Teofilato y Eustaquio. Todo hace suponer que el presbítero Pantaleón, autor de los mosaicos de la catedral de Otranto según sus inscripciones, procedería de tal monasterio de San Nicola1.

Son tres las inscripciones latinas que pueden leerse recorriendo el pavimento de mosaicos de la catedral hydruntina. El arzobispo Jonathas es recordado en las tres como promotor, el monje presbítero Pantaleón en dos como autor, y el rey de Sicilia Guillermo II en las dos más largas, una de 1163 y otra de 1165. Se supone, por tanto, que su realización se sitúa entre ambas fechas. La autoría de Pantaleón deja suponer la presencia de un amplio taller que él organiza y supervisa, del que se sirve para desarrollar su proyecto iconográfico. La gran extensión del mosaico, de poco menos de 600 m2, obliga a pensar en ello.

1. Referente obligado por la proximidad y la dedicación al estudio del mosaico hydruntino, con aportación documental e iconográfica que es muy de agradecer: GIANFREDA, Grazio, Il mosaico di Otranto. Biblioteca Medioevale in immagini (Poema in tre Cantiche), Lecce, ed. del Grifo, 9ª ed., 2005. 
Conviene recordar que el siglo escaso de dominio normando hasta la elaboración del mosaico, no fue una época tranquila, por las incesantes insurrecciones que sacudieron la comarca de Apulia o todo el reino, en particular en las décadas de 1130 y de 1150, culminando en la gran conspiración nobiliaria de 1161 que logró apresar al rey Guillermo I, a su esposa Margarita de Navarra ya sus hijos. Les salvó la lealtad de los arzobispos de Salerno y Mesina, junto a los obispos de Mazara y Siracusa, que arrastraron al pueblo en defensa del rey. Eso elevó aún más el papel político y la influencia social de la jerarquía eclesiástica, cuyos miembros más destacados en realidad se comportaban más como grandes magnates que como prelados².

Guillermo I había logrado ser reconocido por el Papa Adrián IV, a raíz del tratado de Benevento de 1156, como titular del Reino de Sicilia, del Ducado de Apulia y del Principado de Capua, frente a las aspiraciones y amenazas tanto del Emperador Bizantino Manuel I Comneno, como del Emperador del Sacro Imperio Romano Germánico Federico I Barbarroja. El Reino normando se convertía así en protector del Pontificado romano.

La década de 1160 fue pródiga en acontecimientos, además de la conspiración citada, que se prolongó con luchas localizadas pese a estar liberado el rey. Todo ello minó la salud del monarca que murió en 1166, con 46 años, dejando como heredero de sólo 12 años al futuro Guillermo II, que por cinco años quedaba bajo la Regencia de su madre Margarita de Navarra, hasta 1171 en que se le reconoció la mayoría de edad. El reino fue sacudido por terribles terremotos tanto en 1163, contemporáneo al mosaico, como en 1169.

Al entrar en la catedral de Otranto y contemplar los mosaicos, la impresión inmediata es la de quedar transportado a una realidad profunda, quizá mágica, atemporal, una alternativa al presente. Uno se siente perdido, confuso, pero atraído por el caleidoscopio de figuras, de sus guiños y misterios. Yo viajé allá a fin de indagar sobre el vuelo de Alejandro Magno ${ }^{3}$, pero era el mosaico entero quien invitaba a sobrevolar la nave, el crucero y presbiterio, a trepar por el árbol, a saltar entre los círculos, a interrogar personajes, a leer inscripciones e identificar escenas, a sorprender a los animales que pueblan las enramadas. Espontaneidad y sabiduría, gracia y erudición, se conjugan en el Ilamado enigma de Pantaleón, un pavimento del siglo XII del que despega una cultura milenaria ${ }^{4}$.

2. NORWICH, John Julius, Un reino al sol. Sicilia 1130-1194, Granada, Almed, 2008.

3. LÓPEZ DE OCÁRIZ ALZOLA, José Javier, "Iconografía de los viajes en la Edad Media', XIX Semana de Estudios Medievales de Nájera: Viajar en la Edad Media, I.E.R., Logroño, 2009, pp. 423-456.

4. Son básicos los estudios de SETTIS FRUGONI, Chiara, "Per una lettura del mosaico pavimentale della cattedrale di Otranto", Bullettino dell'Istituto Storico Italiano per il Medioevo e Archivio Muratoriano, LXXX, 1968, pp. 213-256. SETTIS FRUGONI, "II mosaico di Otranto: modelli culturali e scelte iconografiche", Bullettino dell'Istituto Storico Italiano per il Medioevo e Archivio Muratoriano, LXXXII, 1970, pp. 243-270. FRUGONI, Chiara, "Chiesa e lavoro agricolo nei testi e nelle immagini dall'età tardoantica all'età romanica", Medievo rurale. Sulle tracce 


\section{Alegorías del tiempo en los Mosaicos antiguos}

No pretendo hacer un estudio general, ni es el momento de intentar una explicación a una temática tan compleja y que se ha hecho acreedora a interpretaciones variadas y contrapuestas ${ }^{5}$. Solamente acercaremos nuestra atención a uno de sus elementos más accesibles, procurando realizar una descripción sencilla, pero analítica, de los elementos iconográficos de este calendario románico de Otranto.

Los griegos creían que las nueve Musas inspiraban la creación cultural. Es bien sabido que de su nombre han derivado tres copiosos manantiales de arte: la Música, los Museos y los Mosaicos. El término romano: Opus Musivum, consideraba la sutil combinación de piezas coloreadas como un arte inspirado por las Musas, o quizá también se refería a la ornamentación de los espacios, fuentes y grutas consagrados a las musae. En ambos casos nadie podía sustraerse al efecto mágico o encantador de las teselas o tesserae componiendo juegos de forma, significado y color con duración permanente.

Los precedentes habría que buscarlos en las pavimentaciones de suelos con guijarros en varios ejemplos de amplias comarcas del Mediterráneo oriental, pero desde el arranque del Helenismo, antes de acabar el siglo IV antes de Cristo, comenzó el empleo del opus tessellatum evidenciado en ciertos mosaicos de especial calidad. Su ámbito abarcó pronto todo el espacio cultural helenizado, incluso la Magna Grecia italiana, preparando su entusiástica incorporación al despegue artístico de Roma. A los ejemplos más sencillos de los siglos II y I antes de Cristo, les sucedieron, con una difusión espectacular, los mosaicos adaptados a la compleja distribución espacial de las villas patricias en los siglos II y III después de Cristo. Puede seguirse su empleo desde Anatolia, Siria y el norte de África, hasta el sur de Galia, pasando por Italia, Sicilia e Hispania ${ }^{6}$.

della civiltà contadina, Bologna, 1980, pp. 321-341. También han sido muy influyentes: WILLEMSEN, Carl Arnold, L'enigma di Otranto. Il mosaico pavimentale del Presbitero Pantaleone nella Cattedrale, Galatina (Lecce), ed. Congedo, 1983. LE GOFF, Jacques, "Il tempo del lavoro. Agricoltura e segni dello zodiaco nei calendari medievali", Storia e Dossier, (dossier no 22), Firenze,1988, FONSECA, Cosimo Damiano, "Lavoro agricolo e tempo litúrgico". Uomo e ambiente nel Mezzogiorno normanno-svuevo, (Atti 8e g. normanno-sveve, Bari, 1987), ed. Dedalo, Bari, 1989, pp. 67-87.

5. Entre los estudios que más han tratado de profundizar en el significado del conjunto musivario de Otranto, se destaca el de Manuel CASTIÑEIRAS, "L'Alessandro anglonormanno e il mosaico di Otranto: una ekphrasis monumentale?", Troianalexandrina, 4, 2004, pp. 41-86. Además de la amplia documentación manejada, como prueba su variada bibliografía, hay que poner de relieve la sutileza de su análisis global, calificando al programa monumental como una ekphrasis, en parangón con el ejercicio retórico de la ekphrasis literaria, es decir la exposición de imágenes parlantes, que desarrollan un tema, en este caso el de la superbia como radix peccati, siendo ejemplarizada en personajes de los más enraizados en el imaginario medieval, como son Alejandro Magno y el Rey Arturo.

6. El profesor Blázquez sugería la posibilidad de que musivarios norteafricanos hacia el siglo III después de Cristo hubieran aportado técnicas y motivos al desarrollo de mosaicos hispanos, dada la afluencia de aportaciones técnicas y culturales en tal sentido. BLÁZQUEZ, José María, Mosaicos romanos de España, Madrid, Cátedra. Historia. Serie menor, 1993, p. 267-271. 
La temática, cuando no es predominantemente ornamental, incide a menudo en figuraciones mitológicas o alegóricas. En ciertos momentos adquieren gran relieve las escenas de caza, de guerra, de tema bucólico o nilótico, y también los espectáculos: teatro, gladiadores y carreras. Entre la gran variedad de motivos nos interesamos por los relacionados con las alegorías del Tiempo, en particular las Cuatro Estaciones, que evocan el ritmo cíclico del año, a través de la fértil vitalidad de la naturaleza. También es frecuente la escenografía que versa sobre faenas agrarias, en particular referentes a la vid. Las Estaciones suelen figurarse por medio de cuatro figuras alegóricas, sean jóvenes de pie, sean cabezas o bustos femeninos, cada uno/una caracterizados por sus atributos. Entre ellos predominan las plantas representativas del ciclo estacional: hojas y flores para la Primavera, espigas para el Verano, hojas de parra, pámpanos, racimos y frutos variados para el Otoño, y ramos de olivo o ramaje seco para el Invierno. Es típico evocar esta fría estación con una domina cubierta con un denso velo ${ }^{7}$. A veces se añaden diademas o guirnaldas, y en ocasiones herramientas: la hoz, el horquillo para aventar la mies, o el corquete de vendimia. Personajes mitológicos con ellos relacionados son los Genios, los Vientos, o las divinidades relacionadas con la fertilidad: Ceres, Ops o Abundantia, y Tellus: la Tierra nutricia. Quizá late en el fondo el ancestral concepto del eterno retorno.

Algunos ejemplos de la mejor calidad se hallan en Túnez, procedentes de las espléndidas villas de las antiguas Thysdrus, actual El Jem, o Hadrumetum, actual Susa, y pueden contemplase en sus respectivos museos, especialmente en el nacional del Bardo de la ciudad de Túnez ${ }^{8}$. No se puede olvidar el singular conjunto de la villa imperial del Casale en Piazza Armerina, en Sicilia, y recordaremos que, entre sus magníficos mosaicos de entre el 320-350, cuenta también con una sala dedicada a las cuatro estaciones. En Ravena prosigue el tema representando la Danza de los Genios de las cuatro Estaciones en la estancia no 10 del Palazzetto Bizantino, mosaico fechable en los siglos $\mathrm{V}$ y VI, momento del gran esplendor de la ciudad, como lo testimonian tantos mosaicos ornamentando e ilustrando el famoso mausoleo de Gala Placidia, además de las singulares igle-

7. Sorprende su frecuencia. Por ejemplo, Las Cuatro Estaciones se reconocen en unos ochenta mosaicos norteafricanos y en casi una cincuentena de mosaicos hispanos. GUARDIA PONS, Milagros, Los mosaicos de la antigüedad tardía en Hispania. Estudios de iconografía, Barcelona, PPU, 1992, pp. 338-340. También son numerosos en regiones de Italia peninsular y en Sicilia, ver: KRAMER, Maja, "A Season in Transition. The picture of Winter in roman mosaics in Hispania: Interpretation and changes in expression and meaning", Anas, 13, 2000, Mérida, pp. 101-123. Respecto a los mosaicos del Mediterráneo oriental, ver: BLÁZQUEZ, José María, "Oficios de la vida cotidiana en los mosaicos del Oriente", Anas, 13, 2000, Mérida, pp. 23-56.

8. Bello calendario de meses en un mosaico romano de El Jem, Museo de Susa, FRADIER, Georges, Mosaïques romaines de Tunisie, Túnez, 1997, pp.88-89. 
sias y baptisterios. Más al norte, en Aquileia destaca sobre todo el excepcional pavimento de mosaico cultual paleocristiano, de principios del siglo IV, con escenas del Antiguo Testamento ${ }^{9}$.

El rechazo de la concepción cosmológica clásica-pagana por el Cristianismo le Ilevó lógicamente a repudiar la astrología tradicional, pues ésta imaginaba la bóveda astral como un segundo Olimpo. Por ello durante mil años no hubo astrólogos reconocidos entre los cristianos europeos, siendo la misteriosa estrella de Belén, que guió a los Magos, el único objeto astral libre de toda sospecha. Pero no se podía borrar tanto peso cultural y es un dato de la potente inercia cosmológica clásica que el Cristianismo, pese a intentos de marcar su sello en los nombres de los días de la semana, tuvo que conformarse con el domingo, mientras de lunes a viernes seguían las referencias a las divinidades clásicas del planetario. Con más fuerza que a las denominaciones se intentó combatir al determinismo astral sobre el carácter y comportamiento humano, tema que incluso preocupó a Santo Tomás de Aquino. Pero resurgieron viejas creencias como por ejemplo la melothesia, que citaremos más adelante.

Sin embargo, la fase aperturista del siglo XII por fin despierta el afán por los descubrimientos astronómicos, con múltiples datos de que eruditos, teólogos y consejeros de reyes vuelven a investigar los secretos del cielo. El Zodíaco y el Horóscopo retoman su papel como referentes temporales ${ }^{10}$.

El ciclo representativo de los meses y el zodiaco en el opus tessellatum catedralicio de Otranto se inscribe por tanto en una tradición que deriva del mundo clásico grecorromano, de fuerte arraigo en el mundo mediterráneo. En Apulia también quedan muestras de mosaicos de pavimento en las catedrales de Trani, Brindisi y Tarento, éste muy dañado. Una vez más podemos aludir a la longue durée de muchas comprobaciones históricas, sobre todo las relacionadas con el ámbito rural, que hacen rebrotar en pleno Medievo el tema de los trabajos agrarios mensuales, un sistema simbólico de representación enlazado con la ciencia

9. Se registran varias alusiones al zodíaco en la Biblia, como por ejemplo en II Reyes 23,5, y se supone que el término hebreo original para designar el zodiaco era mazzarôt o mazzalôt. Se cita también en varios textos: Job 9, 9: Él hizo la Osa y Orión, las Híades y las Casas australes; en Job 38, 31: ¿Puedes tú anudar los lazos de las Pléyades o desatar el cinturón de Orión? (Orión en el texto latino de la Vulgata se cita como gyrum Arcturi). ¿Haces salir a su tiempo la Lucero del alba?, ¿conduces a la Osa con sus crías?; en Amós 5, 8: Él hace las Pléyades y Orión, trueca en mañana las sombras y hace oscurecer el día en noche.

10. SAXL, Fritz, art.: "El renacimiento de la astrología de finales de la Antigüedad" y "La creencia en las estrellas en el siglo XII", en: La vida de las imágenes, Madrid, Alianza ed., 1989, pp. 72-90. En el siglo XII, una de las más explícitas descripciones la ofrece Honorio de Autun, en su obra De Imagine Mundi, P.L., CLXXII, 142: In medio firmamenti sunt duodecim signa per transversam disposita, aequaliter per circuitum distincta. Harum dispositio dicitur graece zodiacus, latine signifer, eo quod fert signa quae animalium habent nomina, Zoon enim dicitur animal. 
astronómica11. En resumen, son los laboratores quienes se hacen un hueco frente a los dominantes oratores y bellatores.

Así, aunque hay un salto cronológico de casi dos milenios, las referencias a los consejos y faenas agrícolas que ofrece Hesíodo en su célebre obra Erga kai Emerai: Trabajos y Días, pueden compararse con las imágenes del ciclo de los meses de Otranto y hallar así curiosas correspondencias. Sobre todo hay que destacar en ambos la constante correlación entre los signos astronómicos, el decurso temporal y la sucesión de faenas agrarias. Por ello, en notas, ofreceremos los textos de Hesíodo que sirven de base a las comparaciones.

\section{Doce meses, doce signos}

Avanzando en el espacio de la nave central de la catedral de Otranto, a la altura de los tramos $5^{\circ}$ y $6^{\circ}$, según la referencia de las columnas que la flanquean, se encuentra el conjunto iconográfico que aúna la representación de los doce Meses y la de los doce Signos Zodiacales ${ }^{12}$. Más de $90 \mathrm{~m}^{2}$ de suelo se dedican a este motivo, de manera que cada uno de los doce círculos se inscribe en un cuadrado que oscila aproximadamente entre 2,5 y $3 \mathrm{~m}^{2}$. Eso supone un despliegue suficientemente amplio de cada escena, lo que permite un tratamiento libre en la composición y en el número y volumen de los componentes. Comparando con otros ciclos del mensario realizados en relieves esculpidos, se abre en Otranto un campo mucho más rico en posibilidades espaciales y sobre todo en la expresividad de líneas y colorido.

11. MANE, Perrine, Calendriers et techniques agricoles (France-Italie, XIle-XIIle siècles), Paris, Le Sycomore, 1983. La autora cataloga ochenta calendarios franceses y casi cincuenta italianos, entre éstos el ciclo musivo de Otranto. De su análisis global se desprende que hay tres focos alimenticios que monopolizan gran número de imágenes: el trigo, la vid y el cerdo. Comprueba que hay un esfuerzo de verosimilitud en los gestos del trabajo y en el utillaje empleado, y señala que en el campo es exclusivo protagonista el varón, sin lugar para la mujer campesina. La presencia animal casi la monopoliza el cerdo. Se comprueba que la latitud y la climatología influyen en la presencia más o menos tardía de las faenas estacionales como la siega y la vendimia. Respecto a la península: CASTIÑEIRAS GONZÁLEZ, Manuel Antonio, EI calendario medieval hispano textos e imágenes (siglos XI-XIV), Salamanca, 1996. PÉREZ HIGUERA, Teresa, Calendarios medievales. La representación del tiempo en otros tiempos, Madrid, Encuentro, 1997.

12. Los teólogos se encargaron de enlazar el simbolismo numérico del doce entre los meses y los apóstoles: HONORIO DE AUTUN, Speculum ecclesiae, (De Ascensione Domini), PL CLXXII, 956: Christus namque est annus Dei benignitatis, factus particeps nostrae mortalitatis. Hujus menses sunt XII apostoli; dies, justi; horae vero, fideles...: Puesto que Cristo es el Año de la benignidad de Dios, partícipe de nuestra mortalidad. Los meses de ese Año son los Doce Apóstoles, los días, los justos, y las horas los fieles. 


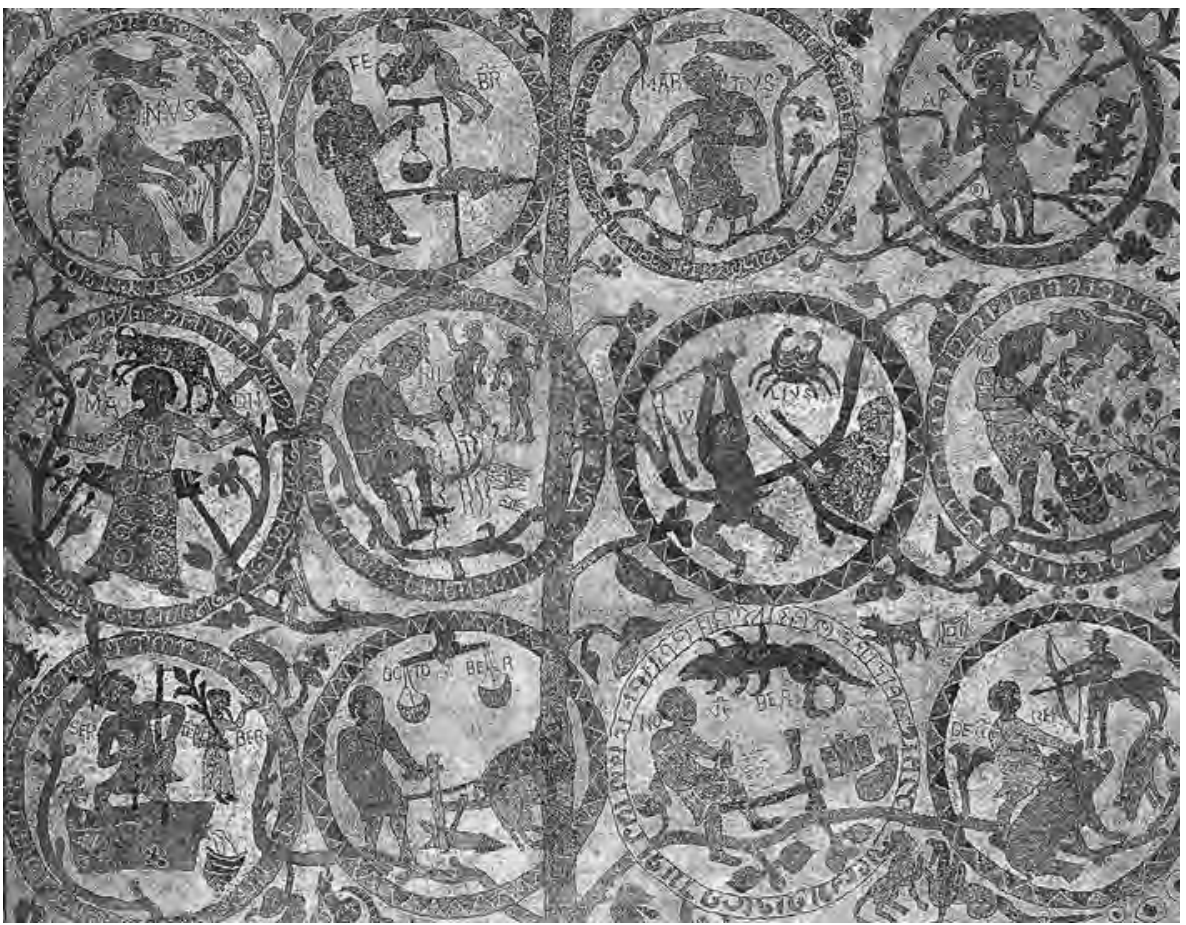

Figura 1. Calendario y Zodiaco. Mosaico de la catedral de Otranto.

Igual que en una pinacoteca y los marcos individualizan y destacan cada obra pictórica, en este amplísimo mosaico, el trazado de círculos regulares o tondos refuerza al mismo tiempo la comprensión del conjunto y permita la concentración en el detalle de cada ejemplo del ciclo.

Ese ciclo anual se ordena cronológicamente, como no podía ser menos, de manera que, de este a oeste y de norte a sur, se escalonan tres bandas de cuatro escenas consecutivas. Primero los cuatro meses que van desde el pleno invierno a la plena primavera: Enero a Abril, después los meses más cálidos: Mayo hasta Agosto, y por fin el declive otoñal: de Septiembre a Diciembre ${ }^{13}$.

13. También hay paralelismos con pinturas murales como las del Panteón Real de San Isidoro de León, cuyas escenas llegan a aproximarse en la temática a las de los meses de Mayo, Junio, Agosto y Diciembre de Otranto. Respecto a los destinatarios, el canónigo regular Hugo de Fouilloy precisa en el prólogo de su Liber avium: dejemos las imágenes pintadas para las gentes sencillas: per picturam simplicium mentes aedificare decrevi, ut quod simplicium animus intellegibili oculo capere vix poterat, saltem carnali discernat; et quod vix poterat auditus percipiat visus. 
El mayor tamaño se reserva a los Trabajos de los Meses, mientras los signos Zodiacales flotan como complementos en la parte superior. Cada mes ostenta su protagonista, una figura humana que en su actividad o atributos expresa de manera concentrada lo propio del tiempo. No suponen una personificación del mes, como en otros calendarios puede ser el caso de Janus o del joven de Abril y el caballero de Mayo, sino en casi todos los casos descienden a la cotidianeidad de las ocupaciones y tareas rústicas, sin otras pretensiones. Los manuscritos divulgan por Occidente el tema de los trabajos de los meses a partir del siglo IX, con gran difusión en los siglos XII y XIII en relieves de fachadas románicas y góticas, de modo que el trabajo manual de los campos es un obligado referente temporal. Destacan en las faenas el cultivo del trigo: arado de surcos, sementera, siega y trilla, así como la vendimia, encubado y matanza del cerdo. Estos trabajos varoniles predominan sobre los femeninos, de hilar, tejer o cocinar ${ }^{14}$.

Como en toda la nave central, el eje del espacio-camino va marcado por el tronco del gran árbol en su parte superior. El trazado del tronco se trenza con los círculos del mensario pasando por encima, por debajo, y secante a ellos, de modo semejante a como hacen las diversas ramas, por lo que se supone que el entrelazarse con el ciclo significa integración con el conjunto musivario de la nave, donde se despliega el inmenso árbol, que todo lo abarca.

Incluso algunas de las figuras parecen apoyar sus pies o reposar sentados sobre las ondulantes ramas. Como tales puede señalarse a los personajes de Enero, Marzo, Abril y Octubre. Pero el caso más evidente es el de la dama que en Mayo extiende sus brazos para abrazar dos ramas verticales con clara intencionalidad. Dejamos la explicación para más adelante. El único mes no cruzado por ramas dentro del círculo es Febrero. También en ocasiones el cruce de ramas por el centro de la escena resulta claramente intempestivo, como en Enero, colándose en la cocina, en Junio invadiendo el centro de la era donde se bate la mies con el mayal, en Octubre y Noviembre, pues estorban en las faenas de arado o sembrado de un campo que lógicamente debería estar despejado.

Los espacios que dejan libres los círculos y las ramas, son habitados por un sinnúmero de animalillos que parecen querer pasar desapercibidos, dado su pequeño tamaño y discretas localizaciones. La fila superior de círculos aparece desprovista, y entre ésta y la siguiente sólo se aprecia junto al círculo de Junio, y debajo de Febrero, un extraño ser, como un pequeño simio con cresta, erguido como una persona, con hocico protuberante y agitando címbalos o sosteniendo bolas en sus manos. Las presencias animales se concentran entre la segunda y tercera filas. Desde el lado izquierdo, en el lateral bajo el círculo de Mayo un perro agazapado acompañado de otro perro algo menor, próximo a Septiembre. Entre los círculos de Mayo y Junio un ave picotea una rama, y bajo ella, entre Sep-

14. SCHMITT, Jean-Claude, La raison des gestes dans l'Occident médiéval, Paris, Gallimard, 1990, pp. 245-251. 
tiembre y Octubre, se estira una liebre de largas orejas. Junto al círculo de Noviembre, frente a Diciembre, se ve a un lobo aullador. Bajo la última fila, al pie de Octubre, por su parte izquierda, se endereza una serpiente enroscada. Entre Noviembre y Diciembre queda reflejada la única escena, representando a dos seres enfrentados. Se trata de un cuadrúpedo no fácilmente identificable, amenazado por un dragón de larga cola. Más adelante hablaremos de ellos.

Los doce círculos tienen forma de anillo y dimensiones similares, aunque varía su decoración, a base de dentellones e incluso de signos que llegan a parecer un remedo de extrañas caligrafías. Dentro del círculo, tal como es habitual, cada mes va acompañado del Signo Zodiacal que al inicio de ese mes se halla presente en su cielo nocturno, aunque más de la mitad de los días del mes, en su segunda mitad, pasen a contemplar un nuevo Signo que perdurará hasta el mes posterior, con el que será relacionado. Sabido es que la banda circundante de la esfera celeste fue dividida por los astrónomos babilonios y griegos en doce partes, cada una de ellas atribuida a una constelación, que fue identificada por medio de unas figuras en correspondencia con las antiguas mitologías ${ }^{15}$.

De hecho, la preeminencia de cada constelación en esa banda tiene una duración bastante desigual, pero la tendencia Ilegó a equilibrarlas en torno a los 30 o 31 días del mes. Por tanto, aunque las fechas concretas de las constelaciones varíen, por comodidad se ha establecido un ciclo de fechas para los Signos Zodiacales, no del todo homogéneo ${ }^{16}$.

El calendario juliano fue adoptado como sistema de calendario cristiano en el Concilio Eclesiástico de Nicea el año 325, por tanto fue de aceptación general dentro de los territorios cristianizados. Así, ese año de 325 el equinoccio de primavera coincidía exactamente con el día 21 de marzo, y podía establecerse, según la fase lunar, la fiesta de la Pascua ${ }^{17}$. De este modo, la Europa medieval

15. En concreto Cayo Julio Higinio (64-17 a.C.) Ilega a describir, en su obra Poeticon Astronomicon, hasta un total de cuarenta y dos constelaciones. Isidoro precisa en sus Etymologiae, lib. 3, XLV, 1: Zodiacus autem circulus est, qui ex linearum quinque angulis, et ex una linea constat. EI Zodiaco es una creación babilónica y representa la rueda de la vida: zodiakos kuklos: en referencia al círculo de los animales, puesto que más de la mitad de los signos van caracterizados por cuerpos de animal, en algunos casos fantásticos. Eratóstenes en el siglo III a.C. asociaba las Constelaciones y el Zodiaco a la fábula, aunque también esta relación de los doce signos del Zodiaco con los doce dioses ya era comentada por el discípulo de Platón, Eudoxo. GONZÁLEZ DE ZÁRATE, J.M., Mitología e Historia del Arte, t.I: De Caos y su herencia. Los Uránidas, Encuentro, Madrid, 2012.

16. Debemos tener en cuenta el cambio que se produjo al pasar del calendario juliano al calendario gregoriano. El primero se instituyó el año 46 antes de Cristo, según la proposición del astrónomo egipcio Sosígenes, y fue así llamado en honor a Julio César, perdurando durante toda la Edad Media gracias a su ordenada concepción temporal, que incluía la adaptación al ciclo solar mediante los años bisiestos, pero que mantenía un pequeño error de cálculo.

17. Respecto a los ajustes del calendario es característico el término: Embolismus: hoc totum ideo fit quia Pascha ante equinoctum et ante .XIIII. Iunam Aprilis qui apud Hebreos primus est agi non licet. La Pascua quedará definitivamente comprendida en el periodo que va entre el 22 de marzo y el 25 de abril. 
seguirá el estilo antiguo, o sea el calendario juliano, tal como es representado, por ejemplo, en las bellas miniaturas a página entera de los meses en el manuscrito de las Très Riches Heures du Duc de Berry, de comienzos del siglo XV. Pero el calendario juliano arrastraba cada año un error de 11 minutos y 14 segundos, lo que debió ser corregido en tiempos del papa Gregorio XIII en 1582. El equinoccio de primavera se estaba alejando progresivamente del 21 de marzo, y se producían complicaciones en torno a la trascendental fijación de la fecha de la Pascua.

Tras discutirse el problema en los concilios de Letrán y de Trento, y previo el informe de los mejores astrónomos, se decidió un reajuste del calendario gregoriano, de modo que en octubre de 1582 se suprimieron 10 días, pasando del 4 al 15 de octubre para corregir el desfase temporal. En Europa esa modificación del Ilamado estilo nuevo fue aceptada en breve tiempo. El señalado desfase es la causa de que en las Très Riches Heures aparecen adelantados en torno a una decena de días el inicio de los Signos respecto al calendario de difusión habitual en nuestra época: Acuario comenzaba el 12 de enero, Piscis el 10 de febrero, Aries el 12 de marzo, Tauro el 12 de abril, Géminis el 13 de mayo, Cáncer el 15 de junio, Leo el 15 de julio, Virgo el 16 de agosto, Libra el 16 de septiembre, Escorpio el 15 de octubre, Sagitario el 14 de noviembre, y Capricornio el 12 de diciembre. Podemos suponer que fechas parecidas a éstas serían las utilizadas en el cómputo medieval, también en el siglo XII, es decir en el momento de realización del mosaico hydruntino.

Con todo, conviene tener en cuenta que durante la larga Edad Media no había uniformidad sobre el cómputo del tiempo, sobre todo por la variedad en el punto de partida, tanto para contar los años, como para el inicio de cada año. En gran parte de Europa se había al fin adoptado la era cristiana, a partir de la supuesta fecha del nacimiento de Jesucristo, pero se mantuvo en gran parte de la península ibérica hasta el siglo XIV la era hispánica, que arrancaba del año 38 antes de Jesucristo, y en Oriente la era bizantina que pretendía remontarse a la fecha del 5508 antes de Cristo, donde suponían la datación de la creación del mundo, casi a la par de lo que había fijado previamente la era alejandrina. Todo esto sin hablar del calendario islámico o de otras culturas de la periferia europea ${ }^{18}$.

18. En bastantes comarcas, tal como se refleja en la documentación medieval, perduró mucho tiempo la calendación romana. Recordando de manera sumaria el sistema de su cómputo mensual, señalamos los tres términos de referencia utilizados: Kalendas es el término empleado para designar el primer día de cada mes, y de ahí deriva la palabra calendario. Siguen las Nonas, que indican el quinto día del mes o el séptimo de los meses romanos largos: Marzo, Mayo, Julio y Octubre. Por fin los Idus, que señalan el día decimotercero, pero que pasa a ser el decimoquinto de los meses romanos largos citados: Marzo, Mayo, Julio y Octubre. Podremos comprobar que en el Zodíaco medieval el paso de un signo a otro viene a aproximarse en cada mes al día de los Idus. 
El comienzo del año era frecuente hacerlo coincidir con la Pascua de Navidad: el 25 de Diciembre, pero otros lugares lo llevaban a la Pascua de Resurrección, en fecha variable pues el Concilio de Nicea había determinado que la Pascua de Resurrección debía celebrarse el primer domingo tras la primera luna nueva de la primavera ${ }^{19}$. En torno a esa época del año, el día 25 de marzo, fiesta de la Encarnación, se iniciaba el año en ciertos países, pero incluso en los territorios controlados por el Imperio Bizantino, la fecha se relegaba al 1 de septiembre. De manera gradual, sin embargo, fue ganando adeptos la fecha actual del 1 de enero, hasta que llegó a hacerse de reconocimiento general.

La comarca de Apulia, que en plena Edad Media seguía envuelta en diversas influencias, pudo también oscilar al albur de unos y otros de los condicionantes indicados sobre la medición del tiempo. Suponemos que durante la etapa de dominio bizantino se pudo mantener inicialmente el comienzo del año tras el máximo estival, en el 1 de septiembre, y en el cómputo de años la era bizantina, pero al afianzarse el control por parte del reino normando de Sicilia, su calendación sería equiparada a las costumbres occidentales, tal como parece indicar el mensario de Otranto.

El tema desarrollado de manera muy característica en el ciclo corresponde a los trabajos agrarios escalonados según la variación estacional que se concreta a lo largo de los doce meses ${ }^{20}$. Iniciamos ahora la presentación pormenorizada de la iconografía de los meses en el mosaico hydruntino. En nota recopilamos algunos textos poéticos de Hesíodo para destacar la prolongada vigencia de sus observaciones astronómico-agrarias y sutiles consejos ${ }^{21}$. Entre las ideas de Hesíodo es muy comentada su alusión a los zánganos ${ }^{22}$.

19. Desde el siglo VII Beda y el Pseudo-Isidoro de Sevilla mencionan dos complejos sistemas de cálculo utilizados para calcular la fecha del domingo de Pascua, en: SCHMITT, JeanClaude, La raison des gestes dans l'Occident médiéval, Paris, Gallimard, 1990, p. 254.

20. Conviene recordar que la palabra latina de la que procede trabajo significa tortura, pues trabajar deriva de tripaliare que alude al tormento del tripalium, compuesto por tres palos: ter pali. SCHMITT, Jean-Claude, La raison des gestes... op. cit., p. 239.

21. Texto original en griego: HESIODI, Theogonia opera et dies. Scvtvm, SOLMSEN, Friedrich (ed.), Oxford, 1970. Versiones en castellano: HESÍODO, Los trabajos y los días. La Teogonia. El escudo de Heracles, LECLUYSE, M.J.; PALAU, E., (versión a cargo de), Barcelona, ed. Iberia, 1972. HESÍODO, Obras y Fragmentos. Trabajos y días. Escudo. Fragmentos. Certamen, PÉREZ JIMÉNEZ, A; MARTíNEZ DÍEZ, A., (versión a cargo de), Madrid, Gredos, 1978.

22. Es muy célebre el pasaje en que avergüenza a los holgazanes, repudiados por todos: HESÍODO, Trabajos y Días: Recuerda siempre mi consejo y trabaja, joh Perses, raza de dioses! para que te desconozca el hambre y que, en cambio, la augusta Deméter de bella corona, te ame y colme tus graneros, pues el hambre es la compañera inseparable del perezoso. Los dioses y los hombres se indignan contra el que vive sin hacer nada, semejante al carácter de los zánganos sin aguijón, que dilapidan el esfuerzo de las abejas devorando su producción. Tú, en cambio, debes empeñarte en trabajar honestamente, a fin de que tus graneros se llenen del constante alimento. El trabajo hace a los hombres opulentos y ricos en rebaños, y trabajando serás más apreciado por los dioses y los hombres, pues desprecian a los perezosos. No envilece el trabajo, sino la ociosidad. (versos 298-307). 


\section{Calendario de Otranto}

1.- IÂNVS en la inscripción, abreviatura en latín de Januarius, es decir: Enero. Círculo rojizo recorrido por una extraña caligrafía, probablemente ornamental. Protagoniza la escena una mujer vestida con túnica talar, ceñida con cingula, tocada con un gorro sobre la cabeza, y cubriendo los pies con medias o botines. Está sentada al borde de un taburete bajo y extiende las manos para calentarlas al fuego de un hornillo de carácter esquemático.

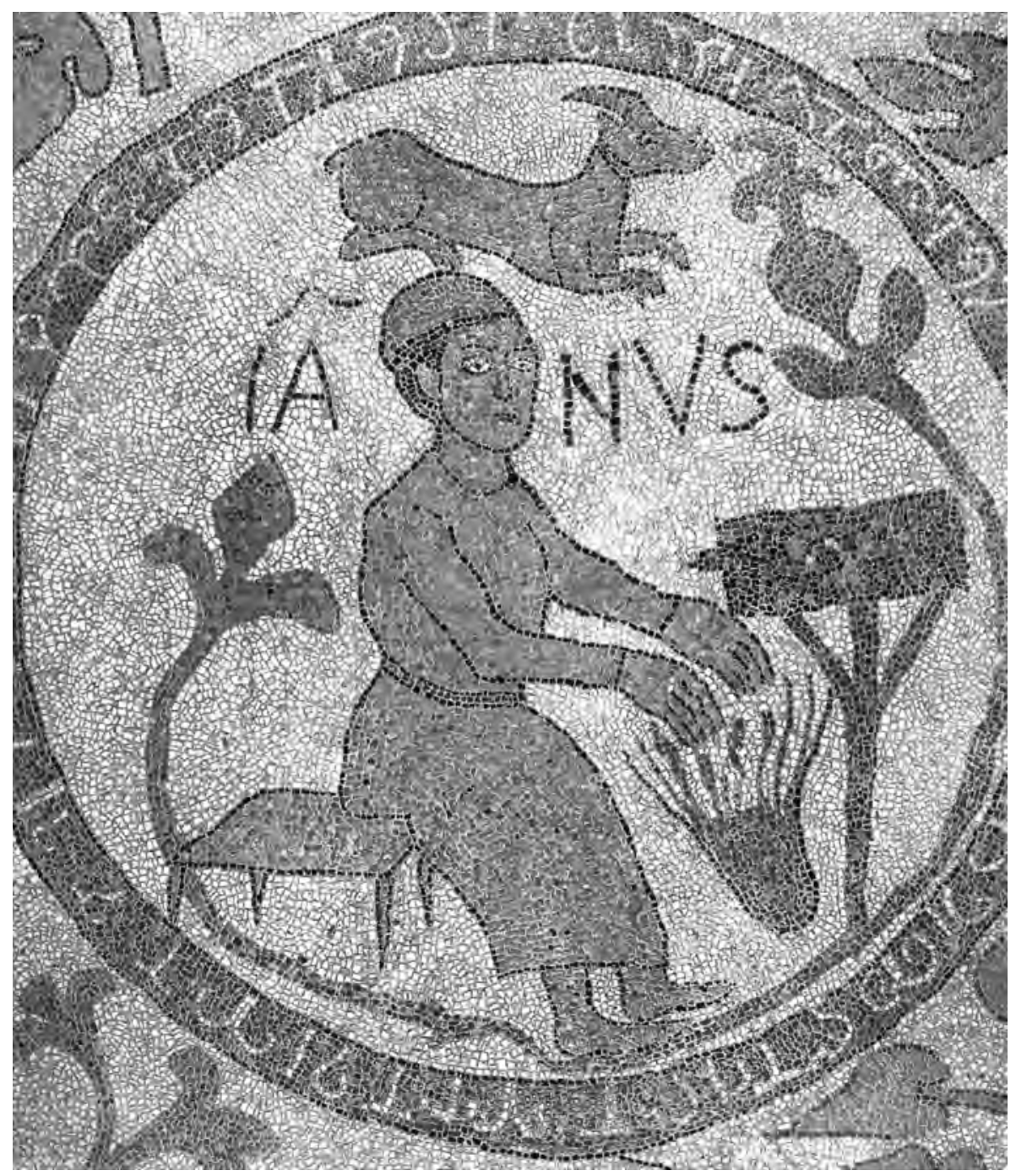

Figura 2. Mes de Enero. Capricornio. Mosaico de la catedral de Otranto. 
Sobre un soporte vertical, ahorquillado, se cruza en sentido horizontal un cilindro, que se supone sirve para el cardado del cáñamo, el lino o la lana. Arriba se muestra el Signo Zodiacal Capricornus cuya aparición en el firmamento se iniciaba en época medieval hacia el 12 de diciembre y ahora el 22, hasta desaparecer el 11 de enero, ahora hacia el 19 o 20. Capricornio se representa en figura de una cabra recostada, mirando hacia el lado derecho, en la misma dirección que la mujer. El gorro, la túnica, y las medias o botas de ésta presentan un color verdoso, que es idéntico al de la piel de la cabra de Capricornio. En realidad el mes de enero lo comparten Capricornus y Aquarius. El elemento más llamativo del conjunto es el fuego, por su color rojizo y las estilizadas Ilamas que ascienden paralelas. Se supone que el ámbito representado es el de una cocina de vivienda popular, donde trabaja en las faenas domésticas el ama de la casa, protegida de los rigores invernales por el calor del hogar23.

2.- $\mathbf{F E B R}^{\wedge}$ en la inscripción, abreviatura equivalente al Februarius latino, es decir: Febrero. Círculo verdoso decorado con dentellones. De nuevo es una mujer la que actúa, de pie y vestida de oscuro ${ }^{24}$. Tiene melena corta y calza pedules rojizos. Con su mano izquierda sujeta la cremallera del Ilar, con su soporte en forma de horca, del que cuelga la olla, aunque no se ve el fuego. Sin éste tampoco tiene mucho sentido su gesto de dar vueltas al espetón donde está ensartado un rostrizo. Flotante sobre el llar se ve un niño alado y desnudo que, vertiendo un cántaro, evoca el Signo Zodiacal Aquarius cuya aparición en el firmamento se iniciaba en época medieval hacia el 12 de enero y ahora el 20, perdurando hasta el 9 de febrero, ahora hasta el 18 o 19. El niño sigue el tipo de representación del eros, que dará lugar, en la iconografía cristiana posterior, a un tipo infantil de ángel. Con su gesto parece dirigirse hacia la mujer, a la que rociaría con el agua del jarro, si ésta fuera representada. El elemento focal del conjunto es el Ilar con la caldera, pero se echa de menos la presencia del fuego, que quizá han soslayado por no repetir la presencia del mismo, ya explícita en Januarius ${ }^{25}$.

23. HESÍODO, Trabajos y Días: Hace encorvarse al viejo y tampoco penetra en la piel delicada de la doncella, que permanece en el interior de la casa, junto a su tierna madre (versos 518-520); Cubre tu cuerpo entonces, si sigues mi consejo, con esponjoso manto y una larga túnica; teje abundante lana en poca trama. (versos 536-538).

24. Como ha demostrado Caroline Bynum, en la Edad Media el único dominio que las mujeres controlaban completamente era el de la comida. BYNUM, Caroline, Jeûnes et festins sacrés. Les femmes et la nourriture dans la spiritualité médiévale, Les éditions du Cerf, Paris, 1994.

25. HESÍODO: Cuidarás de librar tus graneros de la ponzoña de las arañas, y de ese modo no habrá en tu morada más que abundancia y alegría. Sin dificultad alguna llegarás a la blanca primavera siguiente. (v. 475-478). 


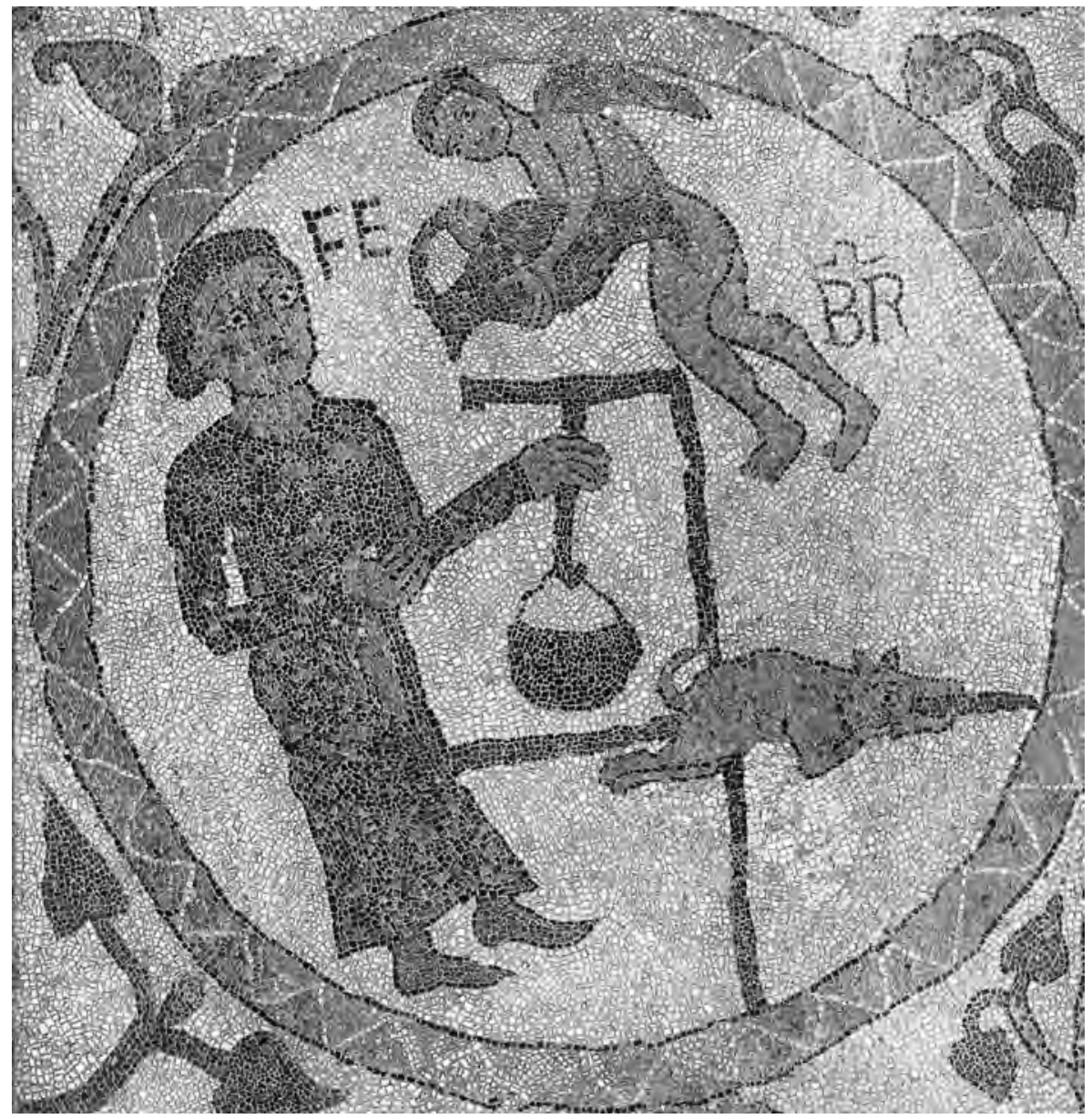

Figura 3. Mes de Febrero. Acuario. Mosaico de la catedral de Otranto.

3.- MARTIVS en la inscripción latina de Martius, Marzo ${ }^{26}$. Círculo rojizo decorado con extraña caligrafía de signos variados. Un hombre joven desnudo, sen-

26. La tradición romana asocia al espinario con el pastor Martius que llevó un importante mensaje al Senado romano y, hasta que no cumplió su tarea, no se detuvo a quitarse una espina del pie. Puede pensarse, por tanto que sea apropiado incluir en el calendario la figura del espinario justo en el mes de Marzo (latín Martius), por la identidad en ambos de denominación: Martius, lógicamente derivados del nombre romano de Ares, el dios Marte, dios de la guerra y de la agricultura, es decir de la fertilidad de los campos, visible en el comienzo de la primavera, precisamente iniciada en Marzo. 
tado en un taburete corto, cruza la pierna y alza el pie izquierdo para extraer una espina, sirviéndose de una larga pinza. No tiene que ver con las faenas o actividades estacionales, pues se trata del clásico espinario ${ }^{27}$.

La anatomía es algo peculiar, pero no está distorsionada. Curiosamente el torso está recto, pero muestra un fuerte giro en el cuello para mirar hacia abajo, y la pierna doblada presenta un cierto verismo. La acción de retirar la espina con las pinzas está encomendada a la mano izquierda, mientras la derecha se ocupa en alisar el pie. Puede apreciarse una semejanza, no solo en el desnudo, sino sobre todo en el rostro, con la figura de Adán enmarcado por un círculo en el mosaico del presbiterio.

La figura del Espinario aparece rodeada de ramajes y hojas, menos en la parte superior, justo sobre su cabeza, en que se ven los dos peces del Signo Zodiacal: Pisces cuya aparición en el firmamento se iniciaba en época medieval hacia el 10 de febrero y ahora el 19 o 20, desapareciendo hacia el 11 de marzo, ahora hacia el 20 de ese mes. Como es característico, ambos peces miran en dirección opuesta, hacia el exterior. Los peces muestran un trazado similar a otros que, en el ábside, surcan las aguas bajo la nave de Jonás, y se parecen más a éstos que a los del costado sur de la nave central. Podríamos recordar que según la llamada melothesia cada signo del Zodiaco ejerce una influencia o al menos hace referencia particular a una parte del cuerpo humano ${ }^{28}$.

Así que la melothesia precisamente relaciona el signo de Piscis con los pies, nada más apropiado para la atención que les profesa el espinario, curando el pie herido, que es una de las partes más vulnerables del cuerpo si no se tiene buen calzado ${ }^{29}$.

27. La derivación sexual en ciertos ejemplos del espinario es documentada por MORALEJO ALVAREZ, Serafín, "Marcolfo, el Espinario, Príapo: un testimonio iconográfico gallego", Primera reunión gallega de estudios clásicos, 1979, Santiago de Compostela, 1981, pp. 331-355. El baldón de lujurioso sobre el Espinario se extendió a partir de la descripción transmitida hacia 1200 por el Magister Gregorius en sus De Mirabilibus Urbis Romae, favoreciendo la visión provocativa el que la famosa estatua helenística del joven desnudo se elevase sobre una columna frente al Palacio de Letrán. No hay tal provocación en el mosaico de Otranto.

28. Además de una Melothesia planetaria, se creía en las virtudes propias de la Melothesia zodiacal, con signos especializados en las partes corporales: Aries, la cabeza, Tauro, el cueIlo, Géminis, los hombros, Cáncer, el pecho, Leo, el corazón, Virgo, el vientre, Libra, las caderas, Escorpio, el sexo, Sagitario, los muslos, Capricornio, las rodillas, Acuario, las piernas, Piscis, los pies. Por alguna razón esta cuestión fue relacionada con el Priscilianismo y por ello condenada en los concilios que tuvieron lugar en Toledo, año 447, y en Braga el año 561. Pese a ello se mantuvieron las creencias en que ciertas partes corporales eran gobernadas desde los astros y también en que los caracteres y hasta la suerte personal quedaba de algún modo en dependencia de ellos.

29. Hay una incontestable prueba de la recuperación de la melothesia en la Europa del siglo XI, según evidencia una miniatura conservada en el B.N de París, MS. Lat. 7028, fol. 154r. El círculo zodiacal, presidido por el Sol explicita el miembro relacionado con cada signo. Ver SAXL, Fritz, art.: "Macrocosmos y microcosmos en las pinturas medievales", La vida de las imágenes, Madrid, Alianza ed., 1989, p. 62, ill. 35a. 
En Apulia también se halla representado el espinario en un relieve de la catedral de Trani ${ }^{30}$.

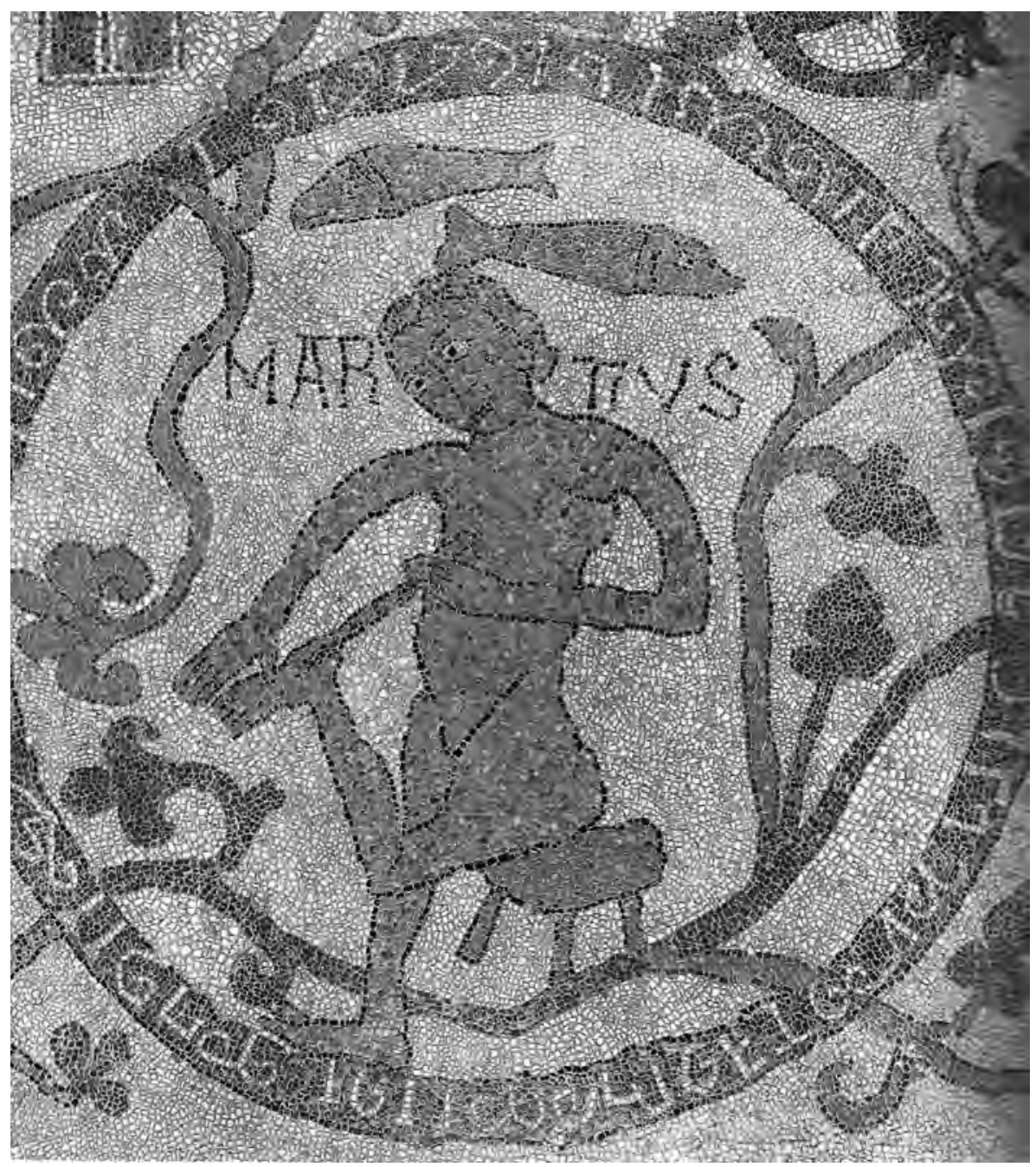

Figura 4. Mes de Marzo. Piscis. Mosaico de la catedral de Otranto.

30. HESÍODO: Sesenta días después del solsticio, Zeus pone fin al invierno. Es cuando la estrella Arturo abandona el sagrado curso del Océano y por primera vez se remonta, brillante al anochecer. Tras ella, la hija de Pandión, vocinglera golondrina, se lanza hacia la luz y entonces nace de nuevo para los hombres la primavera. (v. 564-569). 
4.- APLIS forma abreviada de la inscripción latina de Aprilis, Abril. Círculo que combina en su anillo dentellones alternos rojizos y verdosos. Un pastor, con túnica corta de color verde, calzado con pedules rojos, empuña en la diestra un cayado que apoya en su hombro, y anima a su rebaño a salir y pastar. Se sintetiza la representación de todo el rebaño con solo dos ovejas y una cabra, que se giran hacia el pastor para mirarle. Varias ramas del árbol ambientan la escena campestre, alternando la coloración roja y verde en hojas y ramas, en la cabra, roja, y ovejas, naranja o verde, y en el pastor e incluso en el signo de Aries, con el verde como tono dominante. La figura del Zodíaco es Aries cuya aparición en el firmamento se iniciaba en época medieval hacia el 12 de marzo, ahora el 20 o 21, desapareciendo hacia el 11 de abril, ahora hacia el día 19 o 20. El carnero se arquea sobre la cabeza del pastor, que va acompañada de la inscripción de Abril, y así en el breve espacio superior se concentran el nombre del mes, la expresión del pastor que lo personifica, y el signo del carnero ${ }^{31}$.

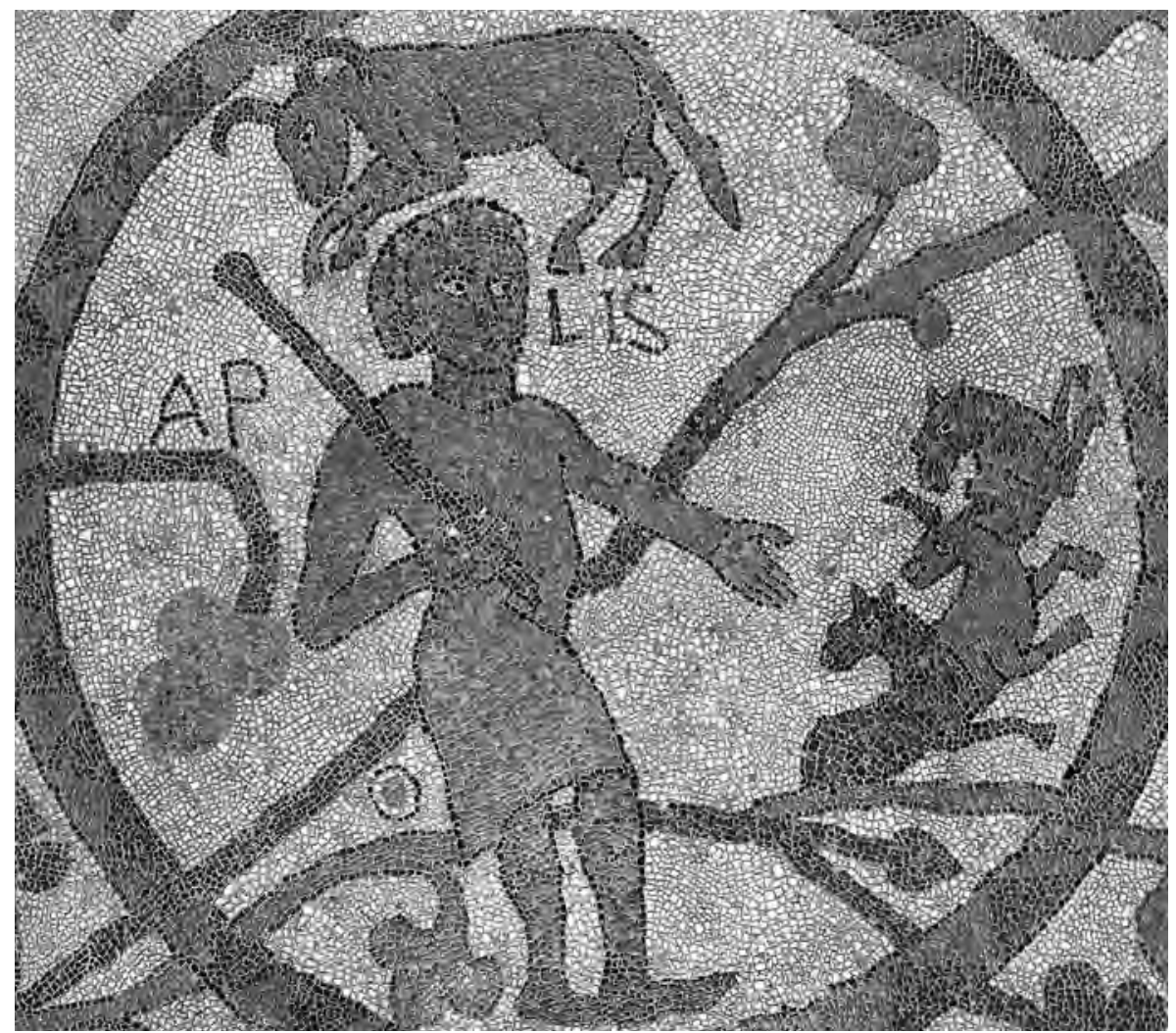

Figura 5. Mes de Abril. Aries. Mosaico de la catedral de Otranto.

31. HESÍODO: Ese día sexto no es favorable para que nazcan mujeres, pero sí para castrar a los cabritos y los corderos de tu ganado; de tal modo es propicio para reunir un excelente 
5.- MADII que aporta una formulación usual en algunos ámbitos de este genitivo latino derivado del clásico Maius, Mayo. Así por ejemplo a veces aparece: Kalendas Madii, o bien Campus Madii, en este último estaría en referencia al característico caballero de Mayo de los calendarios. Círculo rojizo recorrido por signos variados que lo decoran. En el mensario de Otranto destaca la figuración de este mes por la referencia especial, muy cuidada y alejada excepcionalmente del ámbito popular o agrario, con alusión explícita a la festividad pascual, o al tiempo litúrgico que en ella se abre, pues Mayo queda fuera del arco posible de celebración para la Pascua cristiana, que oscila entre el 22 de marzo y el 25 de abril.

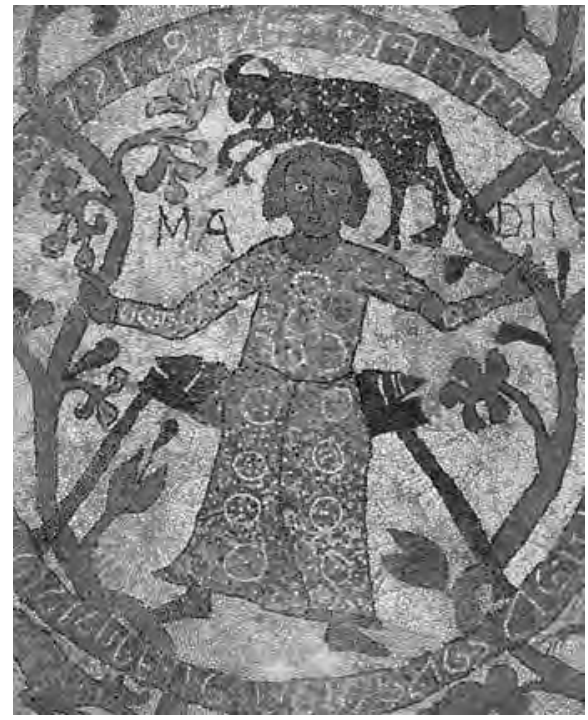

Figura 6. Mes de Mayo. Tauro. Mosaico de Otranto.

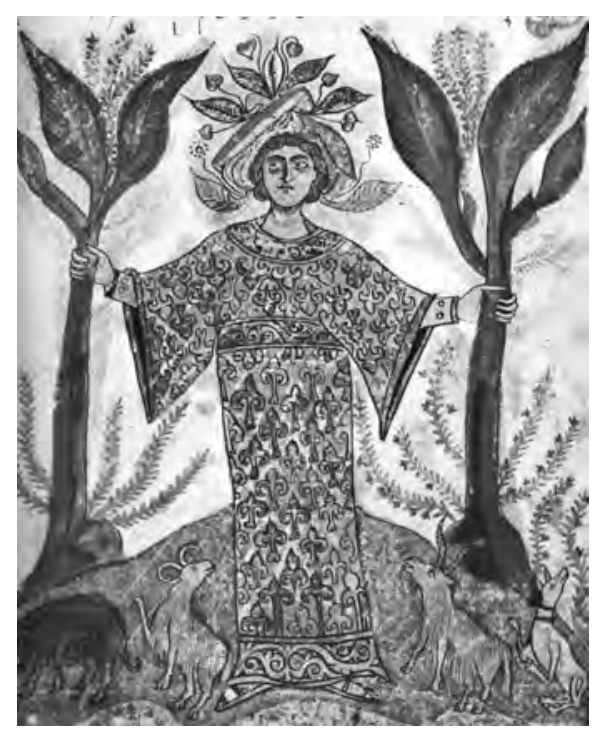

Figura 7. Tellus. Rollo I del Exultet de Bari.

Se trata de la única representación frontal del ciclo. Está dedicada a una joven dama, sin toca de casada, que luce una espléndida túnica estampada, y se alza sedente sobre un amplio asiento guarnecido con cojines, mostrando en primer plano el delantero del hábito talar, con tela doblada y superpuesta sobre la pierna derecha, y dejando colgantes los pies calzados con borceguíes de aire oriental. Con un gesto majestuoso estira sus brazos y aferra dos ramas verticales del entramado que puebla la zona, en conexión supuesta, más que real, con el gran árbol eje que define el espacio de la nave. De manera más pronunciada

rebaño de corderos. (v. 785-787). El día catorce es bueno para domesticar a los carneros y a los bueyes de cuernos retorcidos, al perro de afilados dientes y a los pacíficos mulos, pasándoles la mano por el lomo. (v. 794-798). 
que en otros lugares, en este círculo proliferan los brotes, las hojas, flores y unos frutos que semejan higos. La cabeza de la dama se rodea de una especie de nimbo blanco, intencionado o no, si atendemos al dibujo de una forma arqueada por parte del perfil inferior del cuerpo y patas del toro correspondiente al signo zodiacal. La figura del toro se arquea dirigiéndose hacia la izquierda, con la boca abierta y un acusado color oscuro, en contraste con la claridad de representación de la dama. El Signo zodiacal de Taurus iniciaba su aparición por el firmamento en época medieval el 12 de abril, ahora el 20 o 21, manteniéndose hasta el 12 de mayo, ahora hasta el día 20 o 21.

Ya que hemos aludido a la fiesta pascual, es posible su celebración en la fase inicial del signo de Tauro, pero nunca en el mes de mayo. Puede tener gran interés el comprobar que el año de 1164, precisamente en el momento central de la realización del mosaico que estudiamos, la celebración del Domingo de Pascua, caía justo el 12 de Abril, es decir precisamente en el momento del inicio del signo Zodiacal de Tauro. Eso habría potenciado, sin duda, la elección de un tema tan típicamente Pascual para la escena que combina el mes de Mayo con el signo de Tauro, pero desde luego no por aquél, sino solo en función del signo astral.

Es evidente la dependencia de esta figuración con la que aparece en el rollo del Exultet I del cabildo de la catedral de Bari, del siglo XI, evocando la alegoría de Tellus, la Tierra ${ }^{32}$.

6.- IVNII en la inscripción latina, como genitivo de Junius, Junio. Círculo rojizo recorrido por signos variados que lo ornamentan. El calor supone la madurez de la mies de diversos cereales, a cuya recolección y almacenaje se dedican faenas variadas, que han exigido su prolongación a lo largo de dos meses consecutivos. En Junio un campesino se afana en la labor de la siega, empuñando una hoz con la diestra y atrayendo hacia ella las espigas con la izquierda. Viste túnica corta, como la que los romanos Ilamaban túnica exomis, de color verde, del mismo tono que su sombrero, cónico, y calza pedules. Un haz y una gavilla atados y tendidos, dan muestra de la faena ya realizada. Es interesante cómo se representa al segador en posición de tres cuartos, exagerando el esfuerzo de agacharse, de manera que se comba su hombro derecho en forma de chepa, e in-

32. LE GOFF, Jacques, Una Edad Media en imágenes, Barcelona, Paidós, 2009, p. 31-33, fig. 8. Hay sugerentes referencias a Tellus de San Isidoro de Sevilla, que la describe vestida con túnica, recamada de diversas hojas de los árboles, de verdes hierbas y de hermosas flores... La túnica, con sus brocados de hierbas y flores diversas, simboliza las selvas y las infinitas especies vegetales de las que la Tierra está cubierta. Es Ilamada Madre porque produce frutos abundantes, Grande porque proporciona alimento, Nutricia porque con sus frutos nutre a todos los seres vivos. GONZÁLEZ DE ZÁRATE, J.M., Mitología e Historia del Arte, t.l: De Caos y su herencia. Los Uránidas, Encuentro, Madrid, 2012, pp.198-199. El desarrollo de la botánica en la Edad Media es más prematura de lo que se cree. Un poema alemán del siglo XIII, cuyo primer verso es: Herbas, ut flores, tellus fert multicolores, alude a un sorprendente elenco de 259 plantas medicinales, ofreciendo su nomenclatura. GARCíA GONZÁLEZ, Alejandro, "Herbas, ut flores, tellus fert multicolores", Minerva 21, 2008, pp. 155-194. 
clina la cabeza de modo que hace desaparecer el hombro contrario. Brazos y piernas se disponen rítmicamente paralelos en superposición: alzado el izquierdo sobre el derecho ${ }^{33}$.

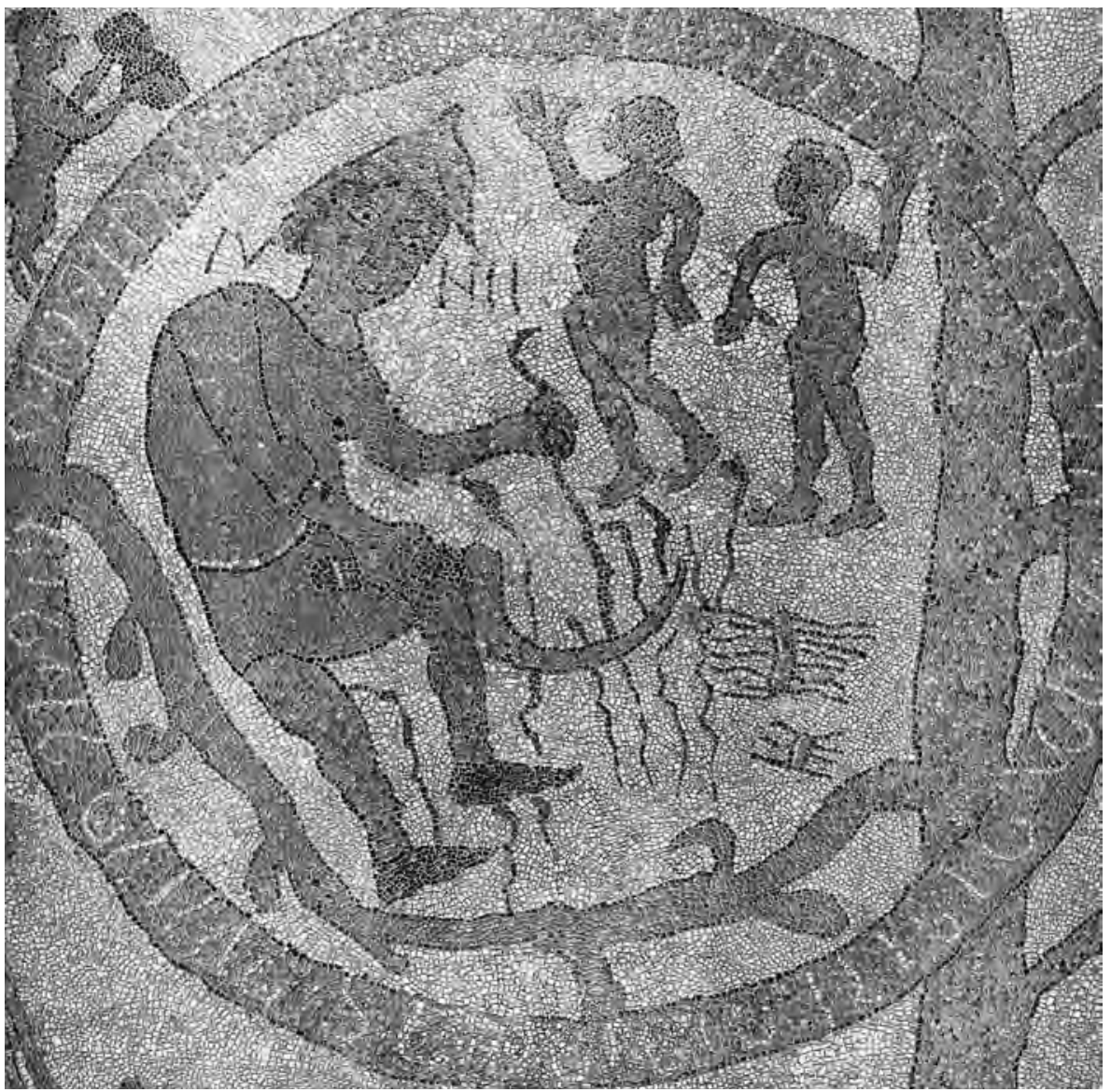

Figura 8. Mes de Junio. Géminis. Mosaico de la catedral de Otranto.

33. HESÍODO: El trabajo bien organizado es para los mortales el primero de los bienes, mientras que el desordenado es el peor de los males. Tus ricas espigas se inclinarán robustas hacia el suelo cuando lleguen a su madurez y Zeus Olímpico les conceda una feliz fructificación. (v. 471-474). Pero si decides arar en el solsticio de invierno, es seguro que cuando te agaches a recoger la cosecha, abarcarás con la palma de una mano las pocas espigas que recojas. Tú mismo podrás atarlas sentado en el polvo y con el corazón afligido, pues cabrán en un cesto que cuando lo transportes a nadie admirará. (v. 479-482). Cuando salga de su refugio el caracol para subir por las plantas, huyendo de las Pléyades, no será ya el momento de cavar las viñas, sino que debes afilar la hoz y espabilar a tus siervos. Abandona los asientos retirados y deja pronto el lecho por la mañana, al llegar la época de la recolección, cuando Helios calienta la piel. Apresúrate, levántate al alba, y acarrea la recolección hasta tu casa, para que sea copiosa la cosecha. (v. 571-577). 
Nos detenemos en los detalles descriptivos para mostrar su evidente comparación con otra de las figuraciones del citado Exultet I de Bari. Se trata de la escena de recolección de la miel, y se puede asimilar la postura del segador de Otranto a lo del representado en el lado izquierdo, que se afana en recoger un panal de miel. Los otros dos que también colaboran en esa tarea no son tan fácilmente comparables a los que simbolizan al signo Zodiacal de Otranto, que corresponde a Gemini. La aparición en el firmamento de este signo se iniciaba en época medieval hacia el 13 de mayo, ahora hacia el 21, perdurando hasta el 14 de junio, ahora hasta el día 21. Los gemelos aparecen desnudos, en posición de tres cuartos, moviéndose y gesticulando con sus brazos, alzándolos y bajándolos. Resulta curioso constatar que la tradición que sugiere paralelismos entre el Zodiaco y el cuerpo humano, precisamente relaciona el signo de Géminis con los brazos.

7.- IVLIVS en la inscripción latina del mes de Julius, actual Julio. Círculo que combina en su anillo dentellones alternos rojizos y verdosos. De nuevo actúa un campesino, que podría ser el mismo de Junio, aunque ahora no lleva sombrero y sus mangas son más largas, afanándose en la tarea de la cosecha. También viste la túnica exomis, tal como los romanos la llamaban. La tensión con que eleva sobre sus brazos el mayal, se estira sobre las puntas de los pies, y hacer revolar el borde de la túnica, imprime a esta figura el carácter más dinámico de todo el ciclo, con mucha diferencia. Algunas figuraciones de hombrecillos representados en miniaturas también presentan gestos enérgicos, pero no es lo más frecuente ${ }^{34}$.

Varían las posibilidades cuando se trata de relieves esculpidos. Así, en un canecillo de Saint-Fort sur Gironde, el espacio forzosamente restringido obliga a una gran mesura de gestos en el que enarbola el mayal. En cambio en la misma comarca de Apulia que Otranto, los frescos del siglo XIII de Santa María della Luce de Casaranello, que representan el martirio de Santa Catalina, se inspiran en el pavimento de Otranto, como lo prueba, por ejemplo, el verdugo que flagela a la santa por el lado izquierdo, que reproduce el gesto del que golpea la mies con el mayal en el mosaico hydruntino.

Volviendo a la escena que nos ocupa, sobre la imaginaria era, el montón de mies es sugerido por una masa oblonga en que se hunden los extremos de una horca o bieldo de tres dientes y de una pala. Forman parte del instrumental usado para aventar y recoger la parva en la era. En la faena, como alternativa a la trilla en que se tritura la mies a base de pasar el trillo sobre ella, era muy frecuente el empleo del mayal o mallo, que se maneja con un mango largo y delgado, unido por un aro con dos palos gruesos, que son proyectados hacia adelante como una maza capaz de desmenuzar la parva. Arriba se muestra el signo Zodiacal de Cancer con el carac-

34. El estirado cuerpo de un campesino blandiendo el mayal se recurva de tal manera que su perfil dibuja una caligráfica S, tal como se ve en una miniatura de las Moralia in Job de Gregorio Magno, Dijon, Bibl. Municipal, MS. 173, fol. 148, en: SCHMITT, Jean-Claude, La raison des gestes dans l'Occident médiéval, Paris, Gallimard, 1990, pp. 246-249, fig. 22,6. 
terístico cangrejo de mar, de color rojo, alzando sus pinzas y apoyando sobre las otras seis patas menores, que según la realidad anatómica deberían ser ocho. Este signo iniciaba su aparición por el firmamento en época medieval hacia el 15 de junio, ahora el 21 o 22, manteniéndose hasta el 14 de julio, ahora hasta el día $22^{35}$.

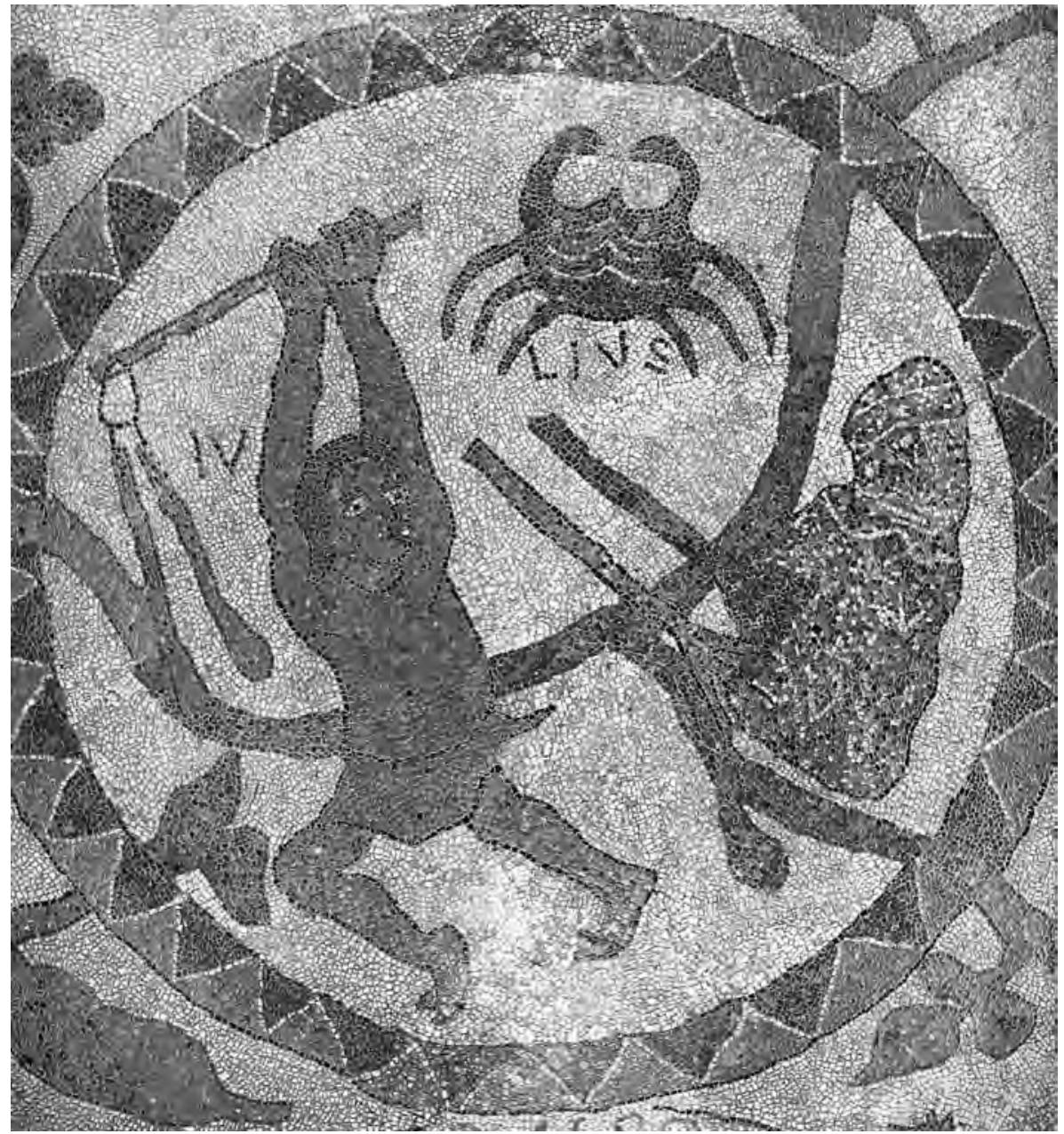

Figura 9. Mes de Julio. Cáncer. Mosaico de la catedral de Otranto.

35. En zonas de Galicia, donde su empleo pudo perdurar más tiempo, a la faena le llaman malla, al apero malle, al mango moca y a lo que golpea pértago o pértigo. HESÍODO: Ordena a tus criados, en cuanto destaque el brillo de Orión, que trillen el sagrado grano de Deméter en una era redonda donde circule el aire. Mide enseguida el grano y guárdalo en los costales. (v. 597-600). En el decimoséptimo día debes esparcir en la era plana el trigo sagrado de Deméter, aventándolo con una ligera brisa. (v. 805-807). 
8.- $\mathbf{A G}^{\wedge}$ tal como se lee en la abreviatura de la inscripción equivalente al Avgustvs latino, es decir Agosto. Círculo rojizo recorrido por tiras verticales o bastoncillos. Se inicia tempranamente la popular faena de la vendimia, que exigirá como fase consecutiva en el mes siguiente la extracción del mosto mediante el pisado de la uva. El mismo campesino que segaba en Junio, con su túnica y gorro cónico verdes y pedules rojos, se dispone a cortar con su navaja el tallo del racimo de uva que depositará en el cuévano ${ }^{36}$. Mete en este recipiente la pierna izquierda, lo que interpretamos como un afán de simultanear en la imagen el habitual acomodo de las uvas con el pie para que quepa más cantidad. Si la vasija fuese de mimbre se le podría denominar cuévano, y si de madera, se corresponde exactamente con lo que en la Rioja se llama comportón o comporta, según su tamaño mayor o menor. Es un tipo de tonel troncocónico de boca más ancha que el fondo, cuyas tabillas verticales van afianzadas con aros metálicos denominados cellos. Solía emplearse madera de chopo para disminuir el peso. Allí se vaciaban los cestos de uva para su transporte.

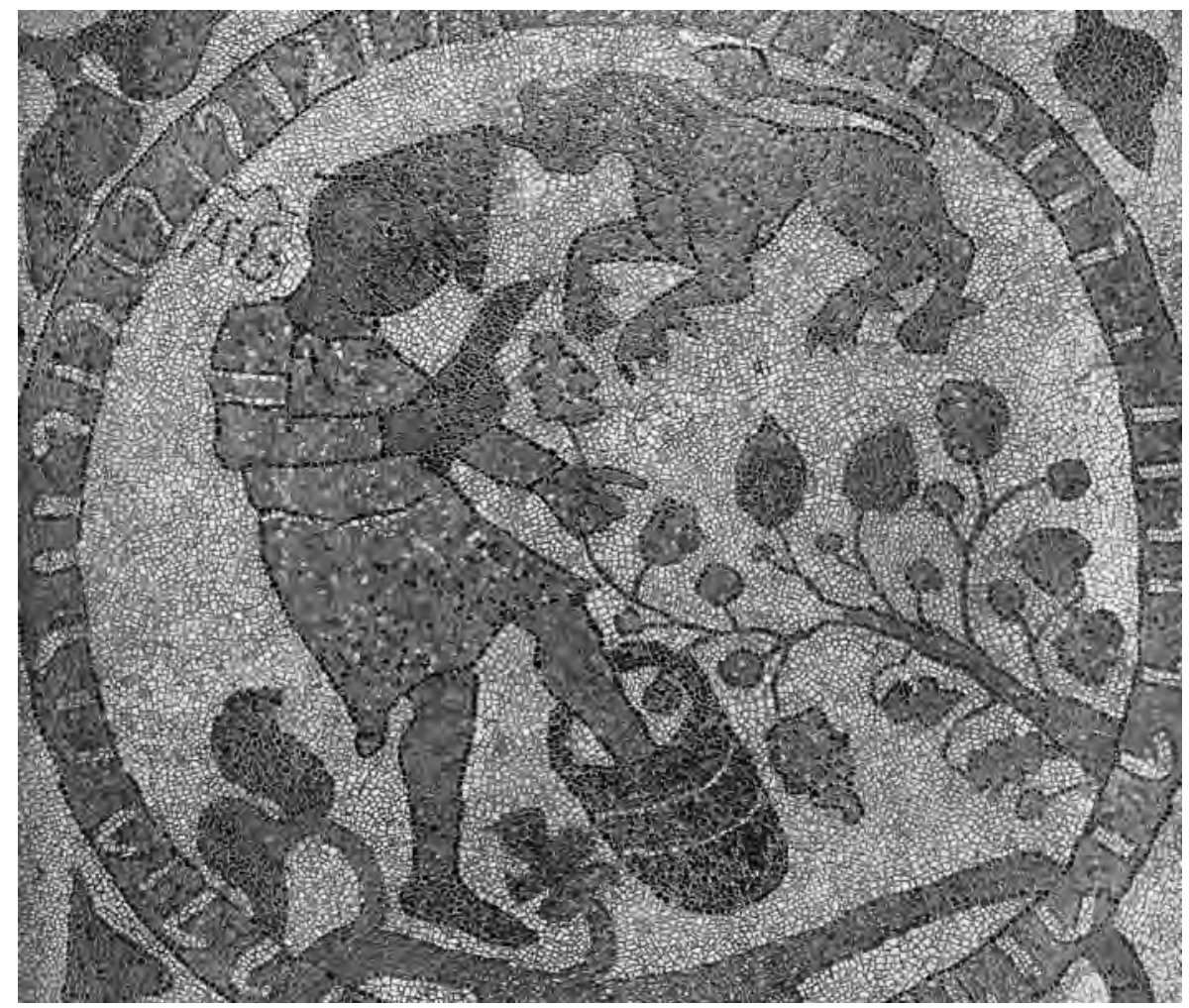

Figura 10. Mes de Agosto. Leo. Mosaico de la catedral de Otranto.

36. El instrumento de corte se muestra recto sin forma reconocible, pero en otros calendarios se puede reconocer el típico corquete o podadera, con forma de pequeña hoz, de extendido empleo y larga perduración. 
Lo representado en la imagen de Otranto, salvando el efecto perspectivo que prima el tamaño del hombre, sugiere un recipiente protegido por aros, y sólido, con apariencia de madera como el citado comportón, más que un cuévano de mimbre y, desde luego, nunca un serón de esparto. Acompaña al signo Zodiacal de Leo cuya aparición por el firmamento se iniciaba en época medieval hacia el 15 de julio, ahora el 23, desapareciendo hacia el 15 de agosto, ahora hacia el día 22 o 23. El adelantar la recolección de la uva a este mes podría obedecer a la climatología cálida de Apulia, pero quizá también a la conmemoración de alguna fiesta por el comienzo de la vendimia. Aunque no consta hasta cuando perduró, recordamos que en época romana se celebraban los $\mathrm{Vi}$ nalia Rustica el 19 de agosto, con sacrificios propiciatorios realizados por el Flamen Dialis que permitían comenzar esas faenas bajo la protección de Júpiter y de otros dioses y genios favorables ${ }^{37}$.

9.- SEPTÊMBER en la inscripción latina, relacionada con el que originalmente era el mes séptimo, Septiembre. Círculo rojizo recorrido por grafías equivalentes a las de Marzo y Mayo. Prosigue el mismo campesino en el proceso que arrancó en la vendimia, para culminarlo en la elaboración del vino. Viste la misma túnica exomis, se cubre con sombrero cónico de color oscuro y realiza la faena descalzo. El escenario es el lagar, en griego lenós, aunque el uso de sombrero parece sugerir que se actúa al aire libre, para no variar de ambiente a lo largo de la serie hydruntina de los meses cálidos y templados. Ayudándose de dos bastones, uno de ellos más corto o más hundido, el cosechero pisa la uva en una tina para extraer el mosto, que sale por una espita lateral para depositarse en una cubeta. El gesto del pisador intenta sugerir el balanceo rítmico característico de esta faena, hundiendo sucesivamente uno de los pies.

Pero el dibujo incurre en flagrante incorrección, pues la pierna izquierda se adelanta al bastón vertical, aunque más abajo reaparece el bastón mientras desaparece el resto de la pierna. Sorprende esta irregularidad dada la corrección general del diseño de las figuras. Quizá la causa radica en la indecisión respecto al enfoque perspectivo de la tina. En el lado derecho parece mostrarnos su frente vertical, por lo que resulta verosímil la situación de la espita en el lateral, y que no veamos media pierna del pisador, aunque tampoco se debería ver el cabo de su bastón. Pero, al otro lado, se nos muestra la pierna derecha completa e incluso se evocan uvas y hojas, de modo que veríamos casi en picado el contenido del tina. En consecuencia creemos que se ha primado la expresividad por encima de la corrección unitaria en la vista perspectiva. El perfil curvo de la cubeta parece convencional, pues sería de esperar un fondo plano. Unas tiras blancas paralelas sugieren un armazón protegido, para que el recipiente, probablemente de madera, resulte completamente estanco. Hacia la derecha

37. HESÍODO: Cuando Orión y Sirio lleguen a la mitad del Cielo, y la Aurora de dedos sonrosados contemple a Arturo, joh Perses!, vendimia entonces, y guarda tus uvas en tu morada. (v. 609-611). 
se muestra el signo Zodiacal de Virgo, cuya aparición por el firmamento se iniciaba en época medieval hacia el 16 de agosto, ahora el 23 o 24, perdurando hasta el 15 de septiembre, ahora hasta el día 22 o 23. Lo representa, como es habitual, una doncella con túnica talar y peinada con trenzas, que porta una gran palma rojiza en la mano izquierda y saluda con la diestra. El ramo o palma que porta presenta un trazado similar al de otros que acompañan a personajes del ábside en su lado norte ${ }^{38}$.

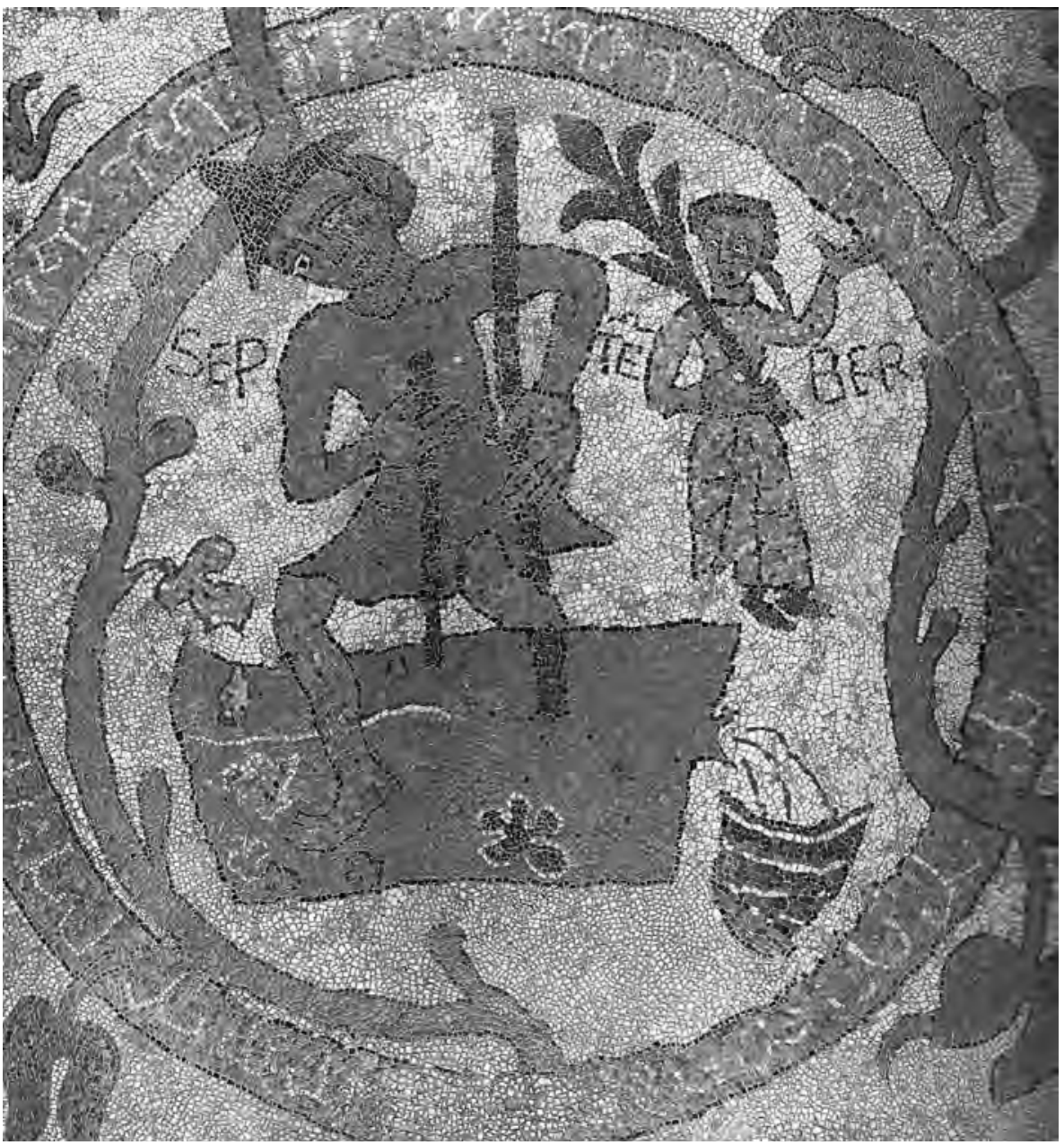

Figura 11. Mes de Septiembre. Virgo. Mosaico de la catedral de Otranto.

38. HESÍODO: Expón los racimos a la luz de Helios durante diez días, sin moverlos en las diez noches. Ponlos a la sombra durante cinco días más, y al sexto vierte en las vasijas esos tan preciados dones de Dionisos, el que inspira la alegría. (v. 612-614). También en el cuarto día puedes abrir los toneles. (v. 819). 
10.- OCTOBER en la inscripción latina del mes de Octubre. Círculo que combina en su anillo dentellones alternos rojizos y verdosos similares a los de Julio y Diciembre. Se representa el arar y labrar otoñal de la tierra ${ }^{39}$. De nuevo el mismo afanoso campesino, vestido de verde, pero mejor abrigado, pues hasta lleva solapa y cubre su cabeza con caperuza flexible de tela, colgante a un lado y con borla. Este popular tocado deriva del gorro frigio, normalmente tejido de lana, y aún hasta hace poco perduraba este tipo o similar en trajes tradicionales de pueblos costeros a lo largo del Mediterráneo, desde los Balcanes hasta Cataluña, con presencia en Italia peninsular y en sus islas, e incluso en Portugal. Como en las demás faenas, la posición del cuerpo resulta muy expresiva del esfuerzo y del gesto que requieren. En este caso es muy natural presentar el cuerpo arqueado, con piernas y hombros adelantados respecto a los riñones, en gesto apropiado para sostener el equilibrio, tras el arado saltarín, sin dejar de empujar. Pese a que se inicia un mes más frío, y a la aspereza del terreno, el labrador va descalzo ${ }^{40}$.

Ciertamente la gran aportación de esta escena radica en la gráfica representación del arado, muy peculiar y cuidadosamente preciso en sus detalles. Deriva del arado romano: aratum, manejado por el arator, provisto de reja: vomer. Varía según cada zona la denominación de cada pieza de madera, que tendería a reforzarse progresivamente con hierro, para endurecer la reja. Va tirado por la pareja de bueyes uncidos en yunta, con yugo que parece apoyado sobre la cruz de los animales, lo que era un sistema rígido, que resulta más eficaz si se trata del yugo cornal, enlazado de forma más flexible, consistente en una sujeción con correas sobre los cuernos. La evolución concluirá mejorando la sujeción mediante el yugo frontal, que mejoró la tracción.

39. HESÍODO: Comienza la labranza al levantarse las Pléyades, hijas de Atlas, y la sementera cuando se oculten. A partir de ese momento permanecen escondidas durante cuarenta días y cuarenta noches, y de nuevo vuelven a aparecer, cuando está avanzando el año, en el momento en que se afilan las herramientas. (v. 383-387). Acarrea hasta tu casa, si la encuentras en montes o campos, una mancera de arado de carrasca, que es la mancera más sólida para hacer faenar a los bueyes. Un seguidor de Atenea la adaptará al timón y la fijará con clavos al dental. Al prepararlo entonces en tu casa, debes disponer de dos arados, uno simple y el otro más compacto. Es la mejor solución porque si se rompe uno, podrás acoplar al otro los bueyes. Los timones más fuertes son de laurel o de olmo; el cuerpo del arado es de encina y la mancera de madera de carrasca. Compra dos bueyes de nueve años. Cuando están en el término de la juventud, se hallan pletóricos de fuerza y son excelentes para el trabajo. No se desmandarán, rompiendo el arado en el surco y dejando sin acabar las labores. (v. 427-440). Al empezar la tarea de labrar, sujetando en la mano el extremo de la mancera del arado y pinchando con el aguijón el costado de los bueyes que arrastran el timón amarrado con una correa, deberá caminar detrás un servidor joven, atrayendo la atención de los pájaros, cuando oculte con su azada las semillas. (v. 467-472).

40. HESÍODO: Desnudo debes estar cuando siembres, desnudo cuando labres, desnudo cuando coseches, si quieres faenar en los trabajos de Deméter en el momento propicio, si quieres que cada cosa crezca en su estación, y si no quieres, careciendo de todo, ir a mendigar en moradas extrañas y quedarte sin nada. (391-395). 


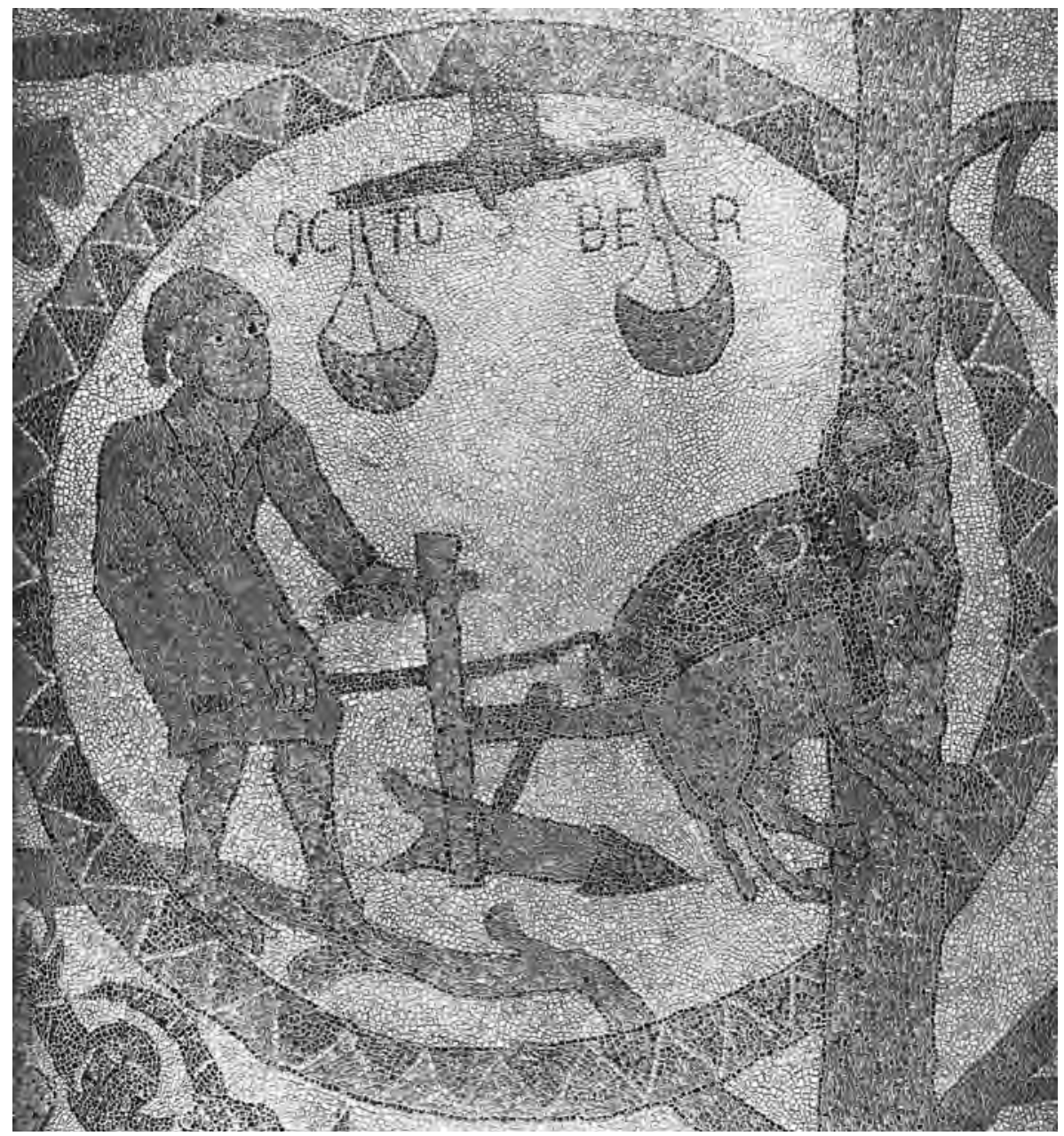

Figura 12. Mes de Octubre. Libra. Mosaico de la catedral de Otranto.

Entre los cuartos traseros asoma la pértiga o timón, que prosigue en la cama, con un enlace oblicuo Ilamado telera, que baja hasta la sólida pieza del dental, sujeta más atrás por la esteva vertical, dirigida desde arriba por la mancera que empuña el labrador. El dental de este peculiar arado tiene forma de flecha, y va necesariamente reforzado con una puntiaguda reja de hierro. El arator guía el arado con su mano izquierda en la mancera y azuza a los animales pinchándoles en los ijares con la aguijada de su diestra. Singulariza a cada buey de la yunta con color diferente, uno claro y otro oscuro. Correspondiente al Signo Zodiacal de Libra aparecen colgando de una mano, que empuña la cruz de la característica balanza, los dos platillos cóncavos, entre los que se intercala la inscripción 
de October. La aparición de Libra en el firmamento se iniciaba en época medieval hacia el 16 de septiembre, ahora el 23, manteniéndose hasta el 14 de octubre, ahora hasta el 22 o 23 de ese mes otoñal.

11.- NOVÊBER en la inscripción, abreviatura equivalente al November latino, es decir Noviembre. Círculo claro recorrido por tiras verticales o bastoncillos rojizos. Prosiguen las labores de la sementera, por parte del agricultor calzado con pedules rojos y ahora con la cabeza descubierta. Recoge con la mano izquierda el extremo de la túnica que, doblado, le permite cobijar las semillas que lanza con la mano derecha para sembrar los surcos ya preparados ${ }^{41}$. Se perciben las semillas, indicadas por punteados en el mosaico, pero no el terreno, pues en esa zona cruza una gran rama con hojas del gran árbol. En cambio se puede observar cinco objetos, uno es la azada con la que ha cavado y que le servirá para cubrir lo sembrado, y el resto describe su pitanza: un rosco de pan, un jamón y un barrilete de vino con su vaso de cuerno para beberlo ${ }^{42}$. Curiosamente, las alusiones a la alimentación acompañan en este calendario a los meses más fríos: Noviembre, Diciembre y Enero. Si nos fijamos en la azada, ésta parece clavarse en la rama del árbol, recordando la forma y función del hacha que está hincada en el tronco del gran árbol un nivel más abajo, bordeando la escena de la construcción del arca de Noé. Su posición puede sugerir alguna función simbólica, aunque como herramienta también el hacha es manejada en dos ocasiones por los hijos del mismo Noé. El signo Zodiacal es Scorpio, representado en gran tamaño, con boca en forma de pico, seis patas y cola enroscada, todo en color rojo. No se ha tenido en cuenta la forma natural de un escorpión ni en la segmentación del cuerpo, ni en destacar el aguijón ni en la disposición anterior de los dos quelíceros, además de las ocho patas. La aparición en el firmamento de este signo se iniciaba en época medieval hacia el 15 de octubre, ahora el 23 o 24, hasta su desaparición hacia el 13 de noviembre, ahora hacia el 21 o 22 de ese mes.

41. HESÍODO: Siembra tu campo cuando aún esté accesible por la sequía; despeja el barbecho en la primavera, para que no esté pesado, por si hay que labrarlo nuevamente en verano. (v. 462-463). Guárdate de sembrar en el decimotercero día del mes comenzado; pero en cambio ese día es excelente para las plantaciones. (v. 780-781). Cuando las Pléyades, las Híades y la fuerza de Orión hayan desaparecido, acuérdate de que ha llegado el momento de labrar, y así será propicio el año a los trabajos de la tierra. (v. 614-617). Presta atención a escuchar el graznido de la grulla, que cada año chilla desde lo alto de las nubes. Su graznido es la señal para la siembra y anuncia la llegada del invierno lluvioso, y desgarra el pecho del hombre que carece de bueyes. (v. 448-451).

42. HESÍODO: Es buen momento para que, entre las rocas umbrosas, disfrutes del vino de Biblos, del pan bien cocido, de la leche de cabras que no crían ya, de la carne de ternera que no ha parido y de la carne de cabritos tiernos. Bebe vino tinto, sentado a la sombra, y hártate de comer, con el rostro expuesto al soplo tibio del viento, al borde de un manantial que corra incesante y claro. Mezcla tres partes de agua con una cuarta parte de vino. (v. 588-596). 


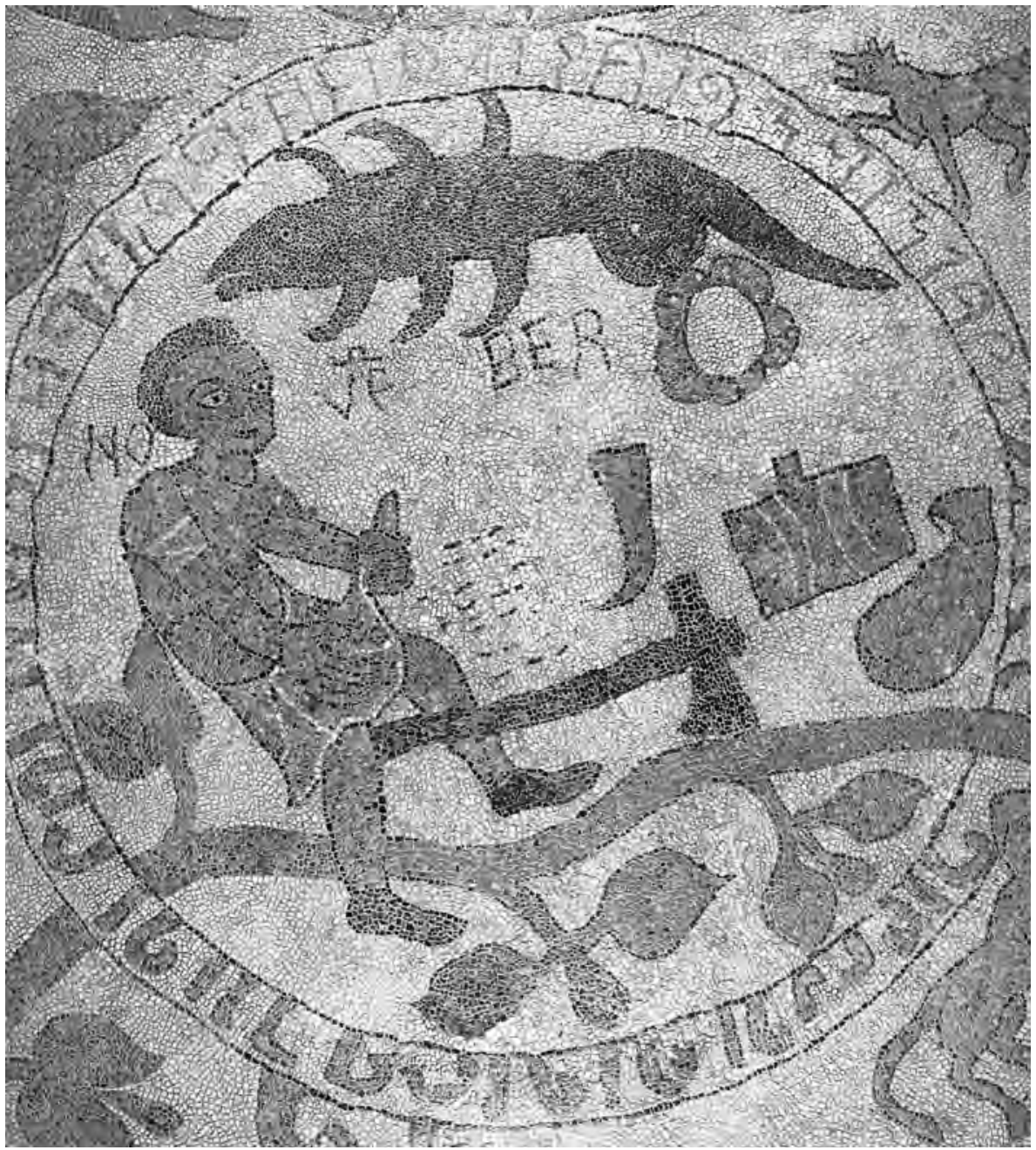

Figura 13. Mes de Noviembre. Escorpio. Mosaico de la catedral de Otranto.

12.- DECÊBER en la inscripción latina abreviada del mes de December latino, o Diciembre. Círculo que combina en su anillo dentellones alternos rojizos y verdosos. El protagonista va caracterizado igual que el joven campesino de Noviembre, pero ahora se ocupa del sacrificio de un robusto jabalí agachado, dotado de fuertes colmillos, al que hunde un cuchillo en la carótida, para simultanear muerte y sangrado. Sin necesidad de gancho, simplemente le sujeta la oreja con la mano izquierda. Se distingue este jabalí grande y verdoso de un lechón de color rosado que asoma por la derecha, sugiriendo que está siendo en- 
gordado para cuando le corresponda el turno. Podemos recordar que la caza del jabalí aparece representada en la zona del ábside, protagonizada por un cazador a caballo que le clava una lanza, ayudado por otro cazador a pie y por un perro. La importancia de la carne de cerdo o jabalí en la alimentación viene subrayada por esa referencia y también porque en el mes de Febrero es un lechoncito el que es asado en el espetón. Aparece como signo Zodiacal Sagittarius, en su habitual representación de un centauro arquero. La aparición en el firmamento de este signo se iniciaba en época medieval hacia el 14 de noviembre, ahora el 22 o 23, manteniéndose hasta el 11 de diciembre, ahora hacia el 21 o 22 del mes.

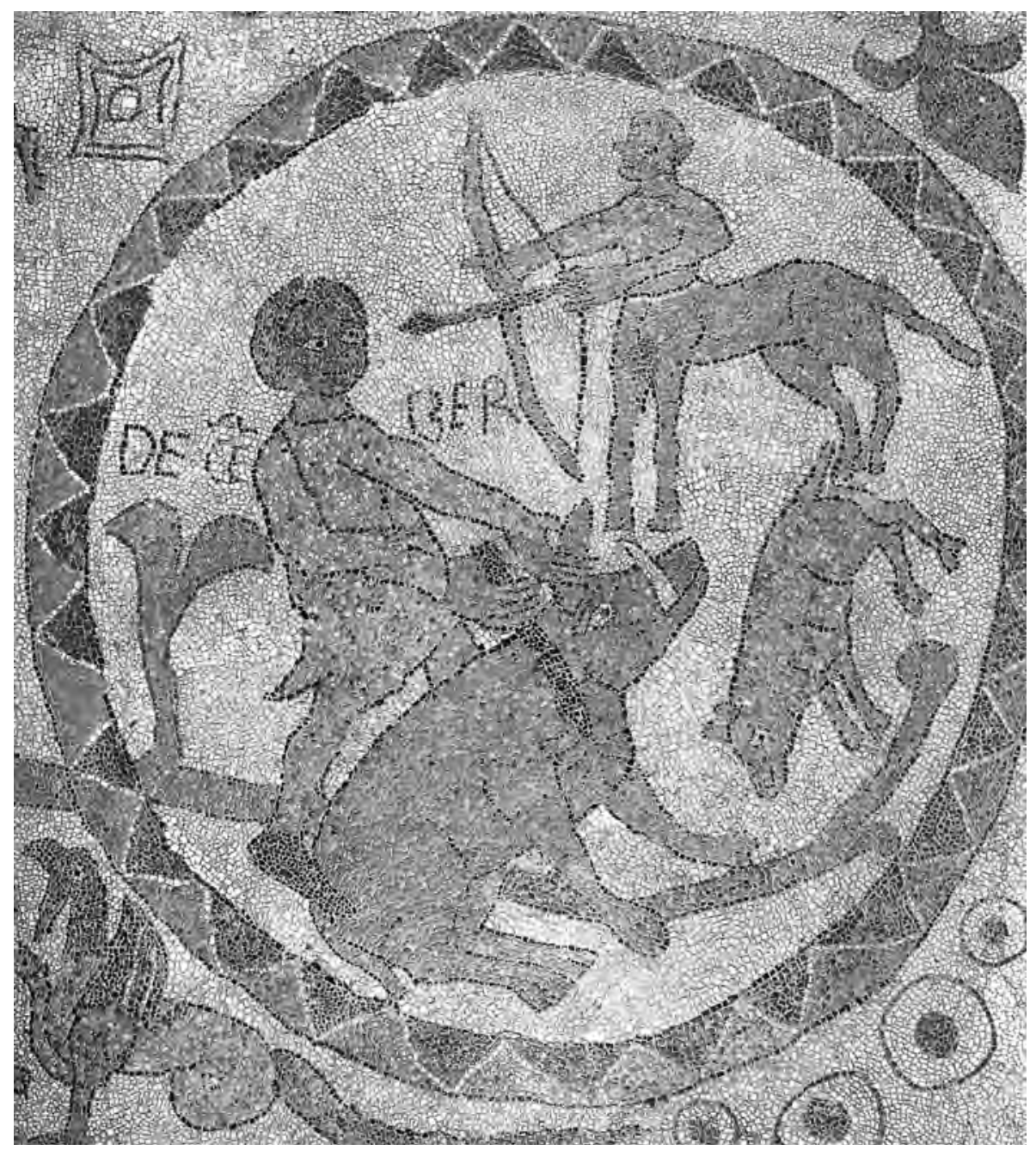

Figura 14. Mes de Diciembre. Sagitario. Mosaico de la catedral de Otranto. 
En este Sagitario, el cromatismo diferencia las dos partes del híbrido: verde para el cuadrúpedo equino y rosada para el busto humano. La posición es de tres cuartos, evitando la presentación tanto frontal como lateral. El sagitario sujeta el arco con la mano derecha disponiéndose con la otra a tensar la cuerda que soltará la flecha. Si comparamos su figura con el otro centauro sagitario del mosaico, también englobado en un círculo del conjunto que decora la zona del presbiterio, vemos sus parecidos y diferencias. El del presbiterio duplica en tamaño al del Zodiaco, y por ello puede percibirse mayor detalle en cabeza y brazos. La misma piel rosada se ve en la parte equina y en la humana, aunque una especie de cinturón marca la separación entre ellas. El del presbiterio se gira hacia atrás y tensa el arco hasta el tope apuntando al ciervo del círculo contiguo, al que ya se ve traspasado por la flecha. Así se evidencia que un mismo motivo iconográfico, con poca variación, puede presentarse tanto en su papel de signo icónico, como también formando parte de un conjunto narrativo. Curiosamente, hacia los pies de la nave, en el lado izquierdo, se repite parcialmente la escena, pues otro ciervo resulta traspasado por una flecha, ahora disparada por el arco de una joven cazadora.

El predominante estacional alude normalmente al frío invernal, pero el atuendo del matarife en este mes es tan ligero como en Junio o Julio, lo que es muestra de que es una faena doméstica realizada a cubierto ${ }^{43}$.

\section{Marco astronómico y temporal: las Constelaciones}

Este ámbito concreto va dedicado por una parte al Tiempo finito, medible, temporal, que va articulado por los Meses, y por otra al Tiempo inmutable y permanente, reflejado en el firmamento de las Constelaciones, protagonizado por el Zodiaco. Puedo suponer que no sólo los emblemas representados en los doce círculos, sino también las figuraciones intermedias caben ser interpretadas como referentes a signos relacionados con las constelaciones. Al menos hay chocantes coincidencias que vamos a enumerar.

Por ejemplo, sorprende la presencia de una serpiente enroscada al pie del punto de unión de los círculos correspondientes a los signos Zodiacales de Virgo y Libra. ¿Por qué no pensar en la constelación de Ophiucus sobre el que

43. HESÍODO: Entonces cubre tu cuerpo, tal como te aconsejo, con un manto espeso y una túnica larga, sobre cuya tela ligera debes acoplar un forro espeso. Cíñetela, para que tu piel no se agite de frío a lo largo de tu cuerpo. Calza tus pies con sandalias hechas con cuero de un buey sacrificado de modo violento, forradas de modo que quede el pelo hacia dentro. Al iniciarse el tiempo frío, cose las pieles de cabritos recién nacidos, bien ceñidas con una correa de nervio de buey, y échatelas sobre los hombros, para protegerte de las Iluvias. Cubre la cabeza con un píleo protector que impida que se te mojen las orejas. Pues son gélidas las mañanas en que sopla el Bóreas. (536-547). 
cruza la constelación de Serpens? ${ }^{44}$ La zona de la cabeza de la Serpiente es precisamente limítrofe de Libra y muy cercana de Virgo. Inmediata se halla la gran estrella Arturo, de la constelación de Bootes: el Boyero. Recordamos que el protagonista de las faenas de Octubre va a ser un boyero, que con un par de bueyes ara el campo.

El círculo del extremo inferior izquierdo del conjunto zodiacal, corresponde al mes de Septiembre, y signo de Virgo. En los espacios curvos a modo de enjutas que lo separan del mes de Mayo y signo de Tauro, se aprecian cuatro animales. A la izquierda, dos perros con sus collares, siendo de mayor tamaño el de arriba y además agazapado en postura de caza; a la derecha, abajo una liebre, que mira a los perros, agachada tras el ápice del círculo de Virgo. Sobre la liebre, apoyada en una rama, un ave de plumaje semioscuro picotea un brote. También en estos casos puede establecerse una razonable referencia a las constelaciones conocidas desde épocas antiguas. Respecto a los dos perros, grande y pequeño, se impone pensar en Canis Major y en Canis Minor, relacionados con Orion, y por tanto situados en el área contigua de Tauro y Gemini. Más al sur de Tauro se muestra Lepus: la Liebre, que en el firmamento es inmediato al Canis Major, junto a los pies de Orion. Queda así completo el conjunto simbólico del gigante cazador Orion, cuya figura es fácilmente reconocible en el cielo invernal por cualquier aficionado a la astronomía. Respecto al ave, si pudiera identificarse como un cuervo, aunque el color no sea negro, podríamos suponer una alusión a la constelación de Corvus: el Cuervo, situada hacia el sur de Virgo. En el mosaico, el ave está próxima de la liebre, pues apenas les separa una rama del árbol. Una antigua creencia aseguraba que la liebre detesta el graznido del cuervo, con lo que justificaban el dato astronómico de que al comienzo de la primavera, en cuanto la constelación de Corvus va a asomar por el este, desaparece Lepus en el horizonte por el oeste.

Junto al círculo de Noviembre/Scorpio, arriba a la derecha, se muestra un lobo, parecido a los perros pero no lleva collar, que alza su pata derecha y parece aullar. Puede representar a la constelación de Lupus: el Lobo, que se sitúa al sur de Libra, inmediato al signo de Scorpio y en el punto de mira del Centauro.

Hacia la base del espacio dedicado en el mosaico al Mensario y Zodíaco, en el triángulo esférico entre Noviembre/Scorpio y Diciembre/Sagitario, quedan dos formas animales afrontadas. El de la derecha se identifica fácilmente con la figura del mítico dragón: un reptil híbrido, con garras de águila, cola larga, enroscada y puntiaguda, amenazando atacar con su hocico picudo. Intenta hacerle frente el de la izquierda, alzando la pata, pero la cabeza parece desfigurada y no se re-

44. Esa figura mitológica de Serpens en ciertos relatos se identifica con Ladón, serpiente enorme, de habla humana, que custodiaba el jardín de las Hespérides, pero que fue herida y muerta por la flecha de Herakles, que así pudo robar las manzanas de oro. Ladón corresponde a la típica serpiente que acecha enrollada al pie de un árbol sagrado. 
conoce qué tipo de cuadrúpedo es. Sus miembros son relativamente fuertes y se alza en parte sobre los cuartos traseros. Dada su anatomía corporal y su cola larga, a menos que haya un descuido del realizador, no se justifica su identificación con el signo de la Ursa Minor, tal como sería lógico. Cabría la posibilidad, dada la equivalencia que a menudo se da entre la evocación de una serpiente monstruosa y de un dragón, que se aluda de nuevo a la constelación de Serpens, que, sobre todo en su cola se halla muy próxima al signo de Sagitario.

De hecho la constelación de Draco, que campea hacia el centro superior del giro del cielo, queda muy por encima de la eclíptica del Zodiaco, aunque su cabeza apunta hacia los signos de Scorpio y Sagitario. La constelación de Draco ${ }^{45}$, en su silueta ondulante parece envolver de tal manera la figura de la Osa Menor, que hasta Tales de Mileto se suponía que sus formas estelares formaban parte del Dragón, pero desde él se consideró forma autónoma. Es de todos sabido que en el extremo de la cola de la Osa Menor está inmóvil la estrella Polar. El Dragón deja también tras su cola a la Ursa Major, la más popular figura del cielo durante todo el año.

De los nueve animales representados en los espacios intermedios que envuelven a los círculos del mensario, únicamente ha quedado un animal que no muestre una fácil referencia astral. Su figura es extraña, de cabeza indefinida y con cresta roja; aparece erguido sobre sus patas traseras, y con las delanteras sujeta unos címbalos, discos o esferas. Los objetos se parecen a los címbalos que entrechoca un perro en el mosaico del presbiterio, justo bajo un burro arpista y el elefante, pero el animal al que nos referimos muestra posición erguida. Aunque con dudas, puede sugerir la evocación del cinocéfalo, criatura híbrida de lejanos orígenes simbólicos y representativos: cynocephali canina capita habent et ora prominentia ${ }^{46}$. Los mosaicos de Otranto figuran varios híbridos androcéfalos de cuerpo animal. En cuanto al cinocéfalo, algunos han emparentado su filiación con la figura de Anubis, el dios chacal en Egipto, característica por su cabeza de orejas enhiestas y hocico puntiagudo. Los cinocéfalos son mostrados con otras poblaciones exóticas en el tímpano románico de Sainte-Madeleine de Vézelay ${ }^{47}$.

45. La constelación de Draco fue calificada de Monstrum mirabile et audax.

46. Sobre la visión medieval de los monstruos, y en concreto sobre los Cinocéfalos, ver: LECOUTEUX, Claude, "Les cynocéphales. Étude d'une tradition tératologique de l'Antiquité au XIle siècle", Cahiers de civilisation médiévale, 24, 1981, p. 117-128. LECOUTEUX, Claude, Les monstres dans la pensée médiévale européenne. Essai de Présentation, Paris, 1993, pp. 20, 6364, 104, 127-132 y 160. BALTRUSAÏTIS, Jurgis, Réveils et prodiges, le gothique fantastique, Paris, 1960. KAPPLER, Claude-Claire, Monstres, démons et merveilles à la fin du Moyen Âge, Paris, 1980. LECLERCQ-MARX, Jacqueline, "Monstres écrits, monstres figurés. Une double tradition médiévale", Quintana, Santiago de Compostela, 4, 2005, pp 37-53.

47. En la Leyenda Dorada se describe a San Cristóbal como un gigante terrorífico, pero en algunas biografías fantásticas lo relacionan con el cinocéfalo: cynocephalorum oriundus genere siendo conocidas algunas representaciones suyas en iconos con digna figura humana, pero con sorprendente cabeza canina. También San Mercurio tenía supuesto origen como cinocéfalo. 
En astronomía se ha llegado a relacionar a la Osa Mayor con el cinocéfalo, a la vez que a la Osa Menor se le Ilamaba Cinosura o Canis.

\section{La Tierra: madrastra y madre}

Como sucinta conclusión de lo expuesto, el análisis del calendario románico de Otranto admira por su lenguaje espontáneo, con sencilla ambientación y animado colorido, que lo convierten en uno de los más expresivos calendarios románicos ilustrados. El perfilado de las siluetas remarcando los gestos refleja una gran sabiduría de composición y una cuidada selección temática.

Pero, más que la forma, interesa asomarnos a su mensaje, que sugiere una singular reflexión sobre los conceptos temporales que la Edad Media expresó a través de imágenes parlantes. Más de un centenar de calendarios esculpidos en iglesias de los siglos XII y XIII carecen de contexto en que apoyar una interpretación iconológica. Por el contrario, el calendario de Otranto se integra en la complejísima sinfonía iconográfica del mosaico completo, un cúmulo de referencias bíblicas, históricas, alegóricas, parenéticas e ilustrativas.

Aunque mantiene la unidad temática que lo diferencia, no es un apéndice inconexo, sino que se enlaza con el gran tema que le precede: la narración de la caída original de Adán y Eva. Su expulsión del paraíso terrenal (Gén. 3, 23): Y le echó Yahvéh Dios del jardín de Edén, para que labrase el suelo de donde había sido tomado, domina al calendario desde el tronco de árbol que sirve de eje al mosaico de la nave. Se sugiere que, por tal mandato, la humanidad es desposeída de la Edad de Oro paradisíaca, a la que también aludía Hesíodo en sus Trabajos y Días (versos 109-119), refiriendo el conocido mito de Pandora (versos 80-99), fácilmente comparable con el desliz atribuido a Eva.

Como consecuencia inapelable llega en el relato bíblico la maldición de la Tierra: maledicta terra, la extrema dureza de la vida y el castigo del Trabajo (Gn. 3, 17-19): maldita sea la tierra por tu causa: con fatiga sacarás de ella el alimento todos los días de tu vida. Espinas y abrojos te producirá y comerás la hierba del campo. Con el sudor de tu rostro comerás el pan, hasta que vuelvas a la tierra, pues de ella fuiste sacado. Porque eres polvo y al polvo tornarás. El tiempo y el trabajo segmentados progresivamente en las doce fases del calendario son la versión explícita de ese mandato. También Hesíodo en su cosmovisión llegaba a las mismas inferencias al devanar sus reflexiones sobre la obligatoriedad de trabajar tenazmente para poder sobrevivir y prosperar siguiendo los preceptos divinos.

Volviendo al texto del Génesis sugerido en el contexto, el correctivo divino recalca: spinas et tribulos germinabit tibi, es decir: la tierra hará brotar para ti espinas y abrojos (Gn 3, 18), frase dirigida a un Adán desnudo e indefenso, amenazado con clavarse tales espinas en los pies descalzos. La idea nos retrotrae al Espinario representado en Marzo (fig. 4), que sin dejar de conectarse con el recuerdo clásico de Martius, no podía menos de suscitar resonancias en un teólogo 
avezado al estudio bíblico, como lo sería el presbítero Pantaleón, enfrascado en representar varias veces a Adán y Eva o Caín y Abel, casi al mismo tiempo del Espinario.

Según la Biblia, la Tierra, maledicta terra, pues es maldecida en Gn. 3, 17, es la madre de la que nació el hombre: Gn. 2, 7: Dios formó al hombre con polvo de la tierra y Gn. 3,19: hasta que vuelvas a la tierra, pues de ella fuiste sacado. La vigente maldición que amenazaba a la madre Tierra y al hijo humano, junto con las penalidades y miserias que conllevaba, no quedan cerradas como un horizonte definitivo en el calendario de Otranto ${ }^{48}$. Se abre un resquicio de esperanza precisamente en un mes primaveral, como es Mayo, bajo el signo de Tauro y con una representación completamente insólita entre la ruralidad de los trabajos agrícolas. Diez escenas de género, con el ritmo de la vida campesina, son interrumpidas en Marzo-Pisces con el Espinario desnudo, y en Mayo-Tauro con una dama entronizada y ricamente vestida, abrazando los ramajes floridos y fructíferos con la misma autoridad elegante con que la Potnia Theron dominaba a las fieras en los antiguos relieves.

En el famoso rótulo pascual del Exultet I del siglo XI conservado en Bari, ciudad también situada sobre la misma costa de Apulia, la exaltación del cántico pascual es representada por la figura de Tellus, la Tierra ubérrima (fig. 7), con los mismos rasgos del mosaico de Otranto (fig. 6). No se puede dudar de la filiación Barense de la dama hydruntina. Este es un dato importante porque la alegoría de Tellus no se queda en reminiscencia arcaica, sino que de la mano de Pantaleón, inspirado en la iconografía de Bari, se transforma en una alegoría pascual de inmediata virtualidad. Celebrar la Pascua era conmemorar la amnistía respecto a la vieja culpa, cambiar el Viejo Adán por el Nuevo Adán, que con su Muerte y Resurrección anunciaba un Cielo nuevo y una Tierra nueva. Como muestra el constante renacer de cada primavera sobre las tinieblas y el rigor mortis de la naturaleza en invierno, la aclamación exultante de la Pascua rompía el dominio de la culpa y del castigo, abriendo una vía de progreso indefinido en oposición al fatalista eterno retorno.

Para terminar, subrayamos un dato muy sugerente. Las dos fechas escritas en el mosaico de Otranto son: 1163 en el presbiterio y 1165 hacia el medio de la nave. Si se indicaron cada una con precisión cronológica, lo que es muy probable, al proceso de confección del Calendario le corresponde el año de 1164. Ese año la gran fiesta de la Pascua, el Domingo de Resurrección, se celebró el día 12 de abril, el mismo día en que el calendario astral de época medieval iniciaba el periodo de Tauro, el signo que acompaña a Tellus, que curiosamente se

48. HESÍODO: La jornada es tan madrastra como madre. ¡Feliz y dichoso aquel que, sabedor de todas estas cualidades de los días, se entrega al trabajo sin ofender a los Dioses Inmortales, observa los augurios de las aves y huye de cometer malas acciones. (v. 825-828). Con estos versos se llega al final de Trabajos y Días de Hesíodo. 
ubica en Mayo, cuando nunca se retrasa hasta tal mes la festividad pascual. Eso significa que el predominante en este caso era el signo Zodiacal. ¿Será muy arriesgado aventurar que la fiesta pascual del 12 de abril de 1164 pudo celebrarse sobre este calendario, contemplando ya la figura de Tellus exultante, regeneradora de la naturaleza primaveral, y sublimadora de los rudos trabajos agrícolas? 